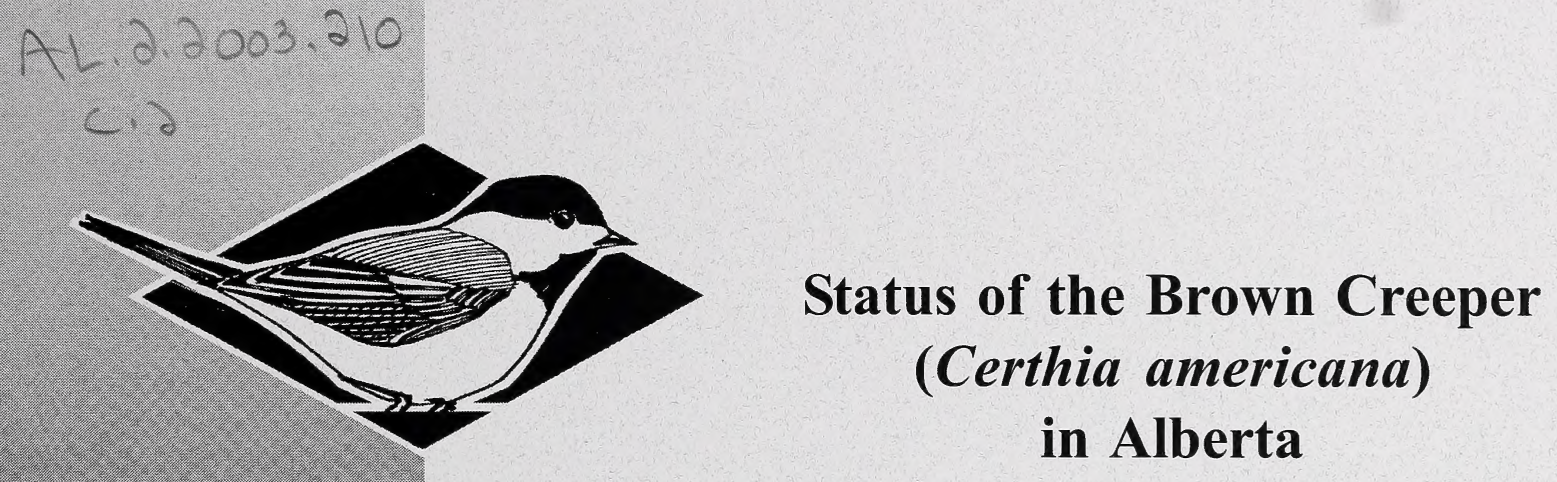

Fish \& Wildifie Division

BIODIVERSITY AND SPEMES AT RISK SEMION

Alberta Wildlife Status Report No. 49
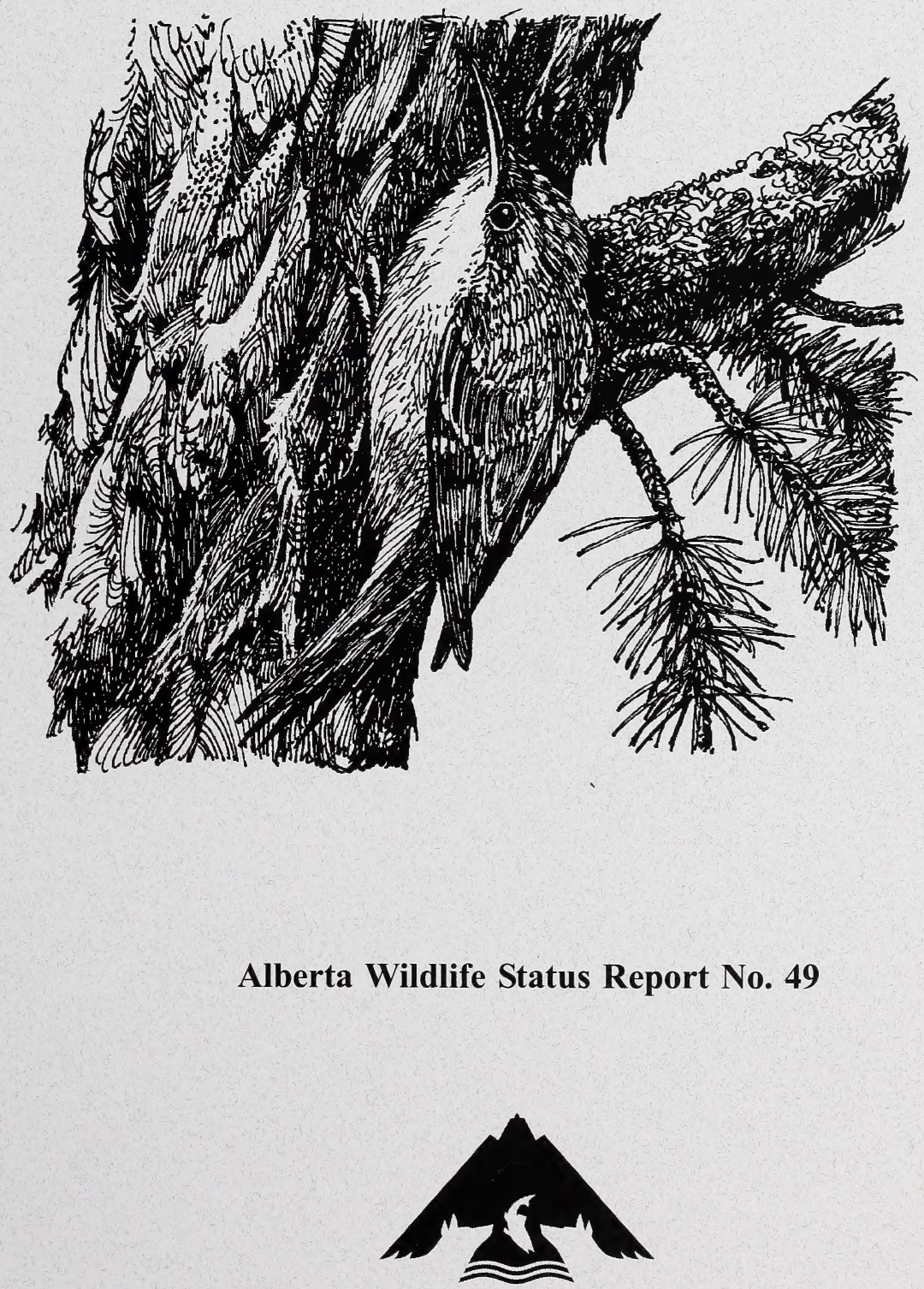

Alberta Conservation Association 
Digitized by the Internet Archive in 2016 


\title{
Status of the Brown Creeper \\ (Certhia americana) in Alberta
}

\author{
Prepared for: \\ Alberta Sustainable Resource Development (SRD) \\ Alberta Conservation Association (ACA)
}

\section{Prepared by: \\ Kevin Hannah}

This report has been reviewed, revised, and edited prior to publication.

It is an SRD/ACA working document that will be revised and updated periodically.

Alberta Wildlife Status Report No. 49

June 2003

Published By:

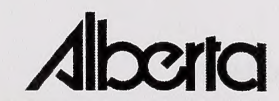

SUSTAINABLE RESOURCE DEVELOPMENT

Fish \& Wildlife

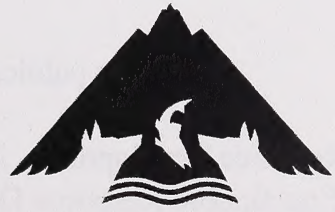

Alberta Conservation Association 
Publication No. T/047

ISBN: 0-7785-2917-7 (Printed Edition)

ISBN: 0-7785-2918-5 (On-line Edition)

ISSN: 1206-4912 (Printed Edition)

ISSN: 1499-4682 (On-line Edition)

Series Editors: Sue Peters and Robin Gutsell

Illustrations: Brian Huffman

For copies of this report,visit our web site at :

http://www3.gov.ab.ca/srd/fw/riskspecies/

and click on "Detailed Status"

\section{$O R$}

Contact:

Information Centre - Publications

Alberta Environment/Alberta Sustainable Resource Development

Fish and Wildlife Division

Main Floor, Great West Life Building

9920 - 108 Street

Edmonton, Alberta, Canada T5K 2M4

Telephone: (780) 422-2079

\section{OR}

Information Service

Alberta Environment/Alberta Sustainable Resource Development $\# 100,3115$ - 12 Street NE

Calgary, Alberta, Canada T2E 7J2

Telephone: (403) 297-6424

This publication may be cited as:

Alberta Sustainable Resource Development. 2003. Status of the Brown Creeper (Certhia americana) in Alberta. Alberta Sustainable Resource Development, Fish and Wildlife Division, and Alberta Conservation Association, Wildlife Status Report No. 49, Edmonton, AB. 30 pp. 


\section{PREFACE}

Every five years, the Fish and Wildlife Division of Alberta Sustainable Resource Development reviews the status of wildlife species in Alberta. These overviews, which have been conducted in 1991, 1996 and 2000, assign individual species "ranks" that reflect the perceived level of risk to populations that occur in the province. Such designations are determined from extensive consultations with professional and amateur biologists, and from a variety of readily available sources of population data. A primary objective of these reviews is to identify species that may be considered for more detailed status determinations.

The Alberta Wildlife Status Report Series is an extension of the general statusing exercises (1996 Status of Alberta Wildlife, The General Status of Alberta Wild Species 2000), and provides comprehensive current summaries of the biological status of selected wildlife species in Alberta. Priority is given to species that are potentially at risk in the province ("At Risk," "May Be At Risk"), that are of uncertain status ("Undetermined"), or those considered to be at risk at a national level by the Committee on the Status of Endangered Wildlife in Canada (COSEWIC).

Reports in this series are published and distributed by the Alberta Conservation Association and the Fish and Wildlife Division of Alberta Sustainable Resource Development. They are intended to provide detailed and up-to-date information which will be useful to resource professionals for managing populations of species and their habitats in the province. The reports are also designed to provide current information which will assist the Alberta Endangered Species Conservation Committee to identify species that may be formally designated as "Endangered" or "Threatened" under Alberta's Wildlife Act. To achieve these goals, the reports have been authored and/or reviewed by individuals with unique local expertise in the biology and management of each species. 


\section{EXECUTIVE SUMMARY}

The brown creeper (Certhia americana) is currently listed as status "Undetermined" in the province of Alberta, based on a lack of published information on this species. The brown creeper is cryptically coloured, resembling the bark of the trees on which it forages. The song and call of the brown creeper are very high-pitched and the species often goes unnoticed on many surveys, probably resulting in an underestimation of population numbers and distribution.

The brown creeper is a short-distance migrant that breeds, and is occasionally a permanent resident, throughout much of the forested region of Alberta. The brown creeper shows a preference for older, conifer-dominated mixedwood forests throughout most of its range, and generally does not occur in forest stands under 80 years of age. The species is dependent on dead or dying trees with sloughing bark to satisfy its unique nesting requirements. Being opportunistic, brown creepers colonize disturbed habitats, such as those created following recent fires or floods, where large numbers of dead and dying trees create an abundance of favoured breeding and foraging habitat. The brown creeper is also unique in its foraging behaviour; it pecks and probes the bark fissures and cracks of large trees in search of its favoured prey of arthropods.

The brown creeper is limited by the abundance and distribution of suitable nest sites and high-quality foraging habitat. The brown creeper is negatively affected by resource development, such as forestry and energy sector activities, which result in habitat loss and fragmentation. Current silvicultural practices promote the harvesting of older forest stands, the "unmixing" of mixedwood stands, the suppression of forest fires, and intensive salvage logging of burned forests, all of which have negative effects on this species.

Although the exact number of brown creepers within the province of Alberta is not known, the species' population appears to be stable. However, with such unique life-history characteristics and dependence on older forests, those factors that negatively affect both breeding and foraging habitats are likely to worsen over time. If measures are not taken to ensure the protection and maintenance of suitable habitat for this species, populations within the province may begin to decline. 


\section{ACKNOWLEDGEMENTS}

This report would not have been possible without the contributions of numerous individuals who generously provided their unpublished data, valuable comments, and precious time. Many thanks to Fiona Schmiegelow (University of Alberta), Susan Hannon (University of Alberta), Curtis Stambaugh (University of Alberta), Dave Stepnisky (University of Alberta), Theresa Morcos (University of Alberta), Cindy McCallum (University of Alberta), Warren Fleming, and Bruce Harrison (University of Alberta) for contributing data and time. An earlier version of this report benefited greatly from comments by Matt Besko (Alberta Sustainable Resource Development), Sherry Feser (Alberta Conservation Association), Robin Gutsell (Alberta Sustainable Resource Development), Sue Peters (Alberta Conservation Association), Susan Hannon, Fiona Schmiegelow, and Curtis Stambaugh. Although there is still much to learn about avian species in the province of Alberta, the tremendous amount of innovative research and inventory work within the past decade is truly humbling and should be commended.

Preparation of this report was funded by the Wildlife Management Enhancement Fund of the Alberta Conservation Association and the Fish and Wildlife Division of Alberta Sustainable Resource Development. 



\section{TABLE OF CONTENTS}

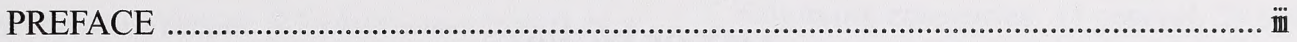

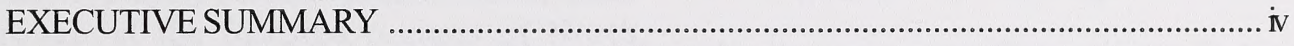

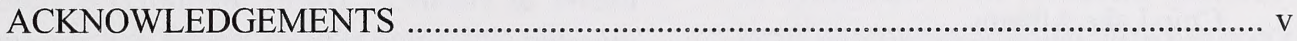

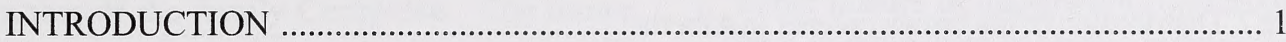

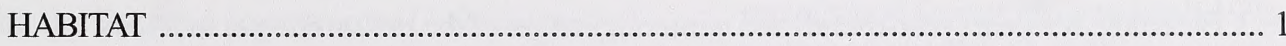

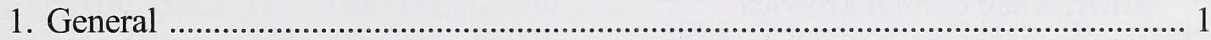

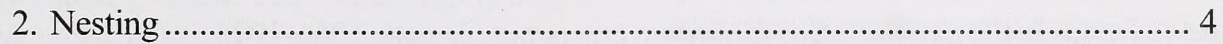

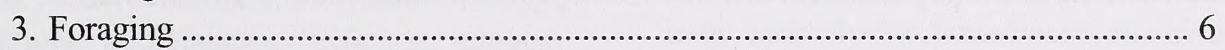

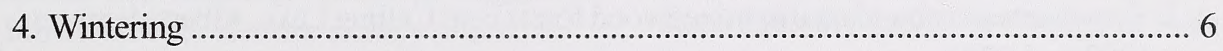

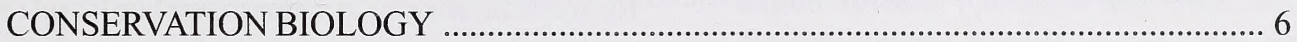

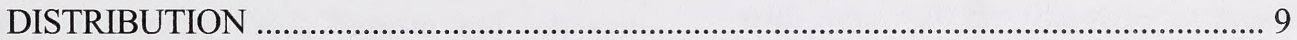

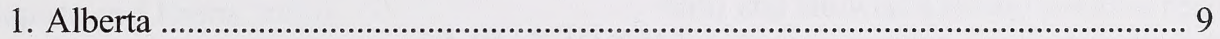

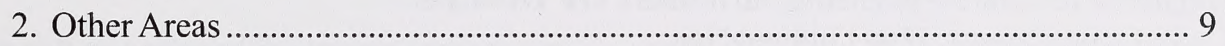

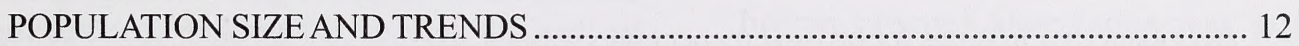

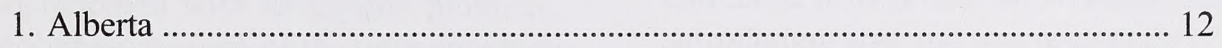

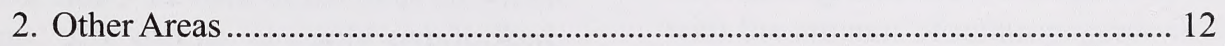

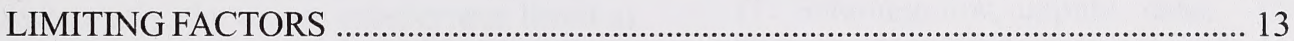

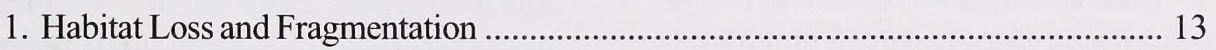

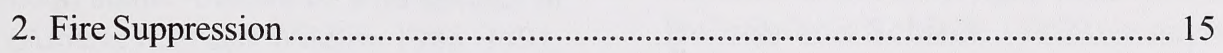

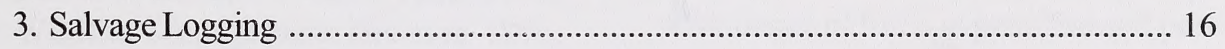

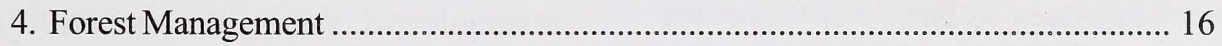

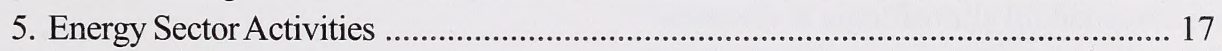

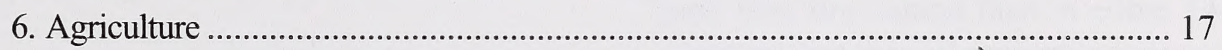

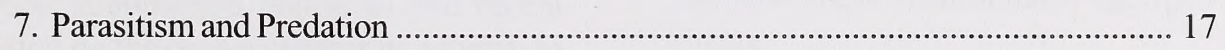

8. Winter and Migratory Stop-over Habitat .............................................................. 17

9. Human Disturbance .................................................................................... 18

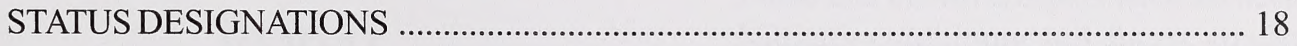

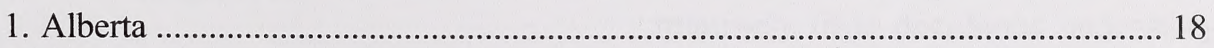

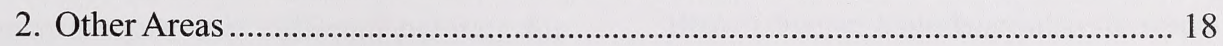

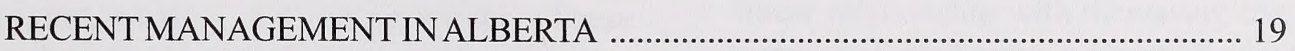

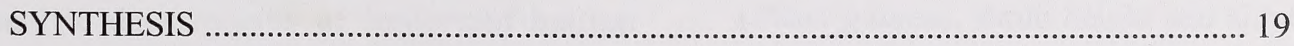

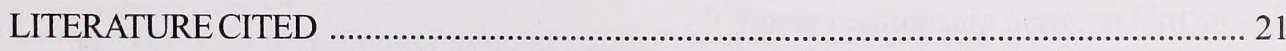

APPENDIX 1. Definitions of selected legal and protective designations ............................... 29 


\section{TABLE OF CONTENTS cont.}

\section{LIST OF FIGURES}

Figure 1. Comparisons of brown creeper abundance at several time intervals following fire near Chip Lake Alberta 3

Figure 2. Distribution of the brown creeper in Alberta ....................................................... 10

Figure 3. Breeding, resident (year-round) and wintering ranges of the brown creeper in North America and Central America

Figure 4. Trends in the population of the brown creeper in Canada, 1966-1996 13

Figure 5. Brown creeper abundance in mixedwood forest near Calling Lake, Alberta between 1993 and 2001 15

\section{LIST OF TABLES}

Table 1. Abundance weightings for brown creeper observations 5 


\section{INTRODUCTION}

The brown creeper (Certhia americana) is a small, cryptically coloured passerine bird, found throughout the forested regions of North America (Godfrey 1986). Unique to North America, the brown creeper represents the only member of the family Certhiidae. The brown creeper was formerly regarded as conspecific with the Eurasian treecreeper (C. familiaris) of Europe, central Asia, the Himalayas, and northern China (Vaurie 1957, Paynter 1967). However, recent evidence based on morphology, vocalizations, and roosting behaviour suggest that the brown creeper is more closely related to the short-toed treecreeper ( $C$. brachydactyla) of central and southern Europe, and northwestern Africa (Thielcke 1962, Bapista and Johnson 1982, Bapista and Krebs 2000).

Both the call and song of the brown creeper are high-pitched, making the species difficult to detect. Combined with its cryptic plumage, which resembles the bark of the trees on which it forages, this species is easily overlooked. Consequently, the brown creeper was listed as "Undetermined*" in the 1985, 1991, 1996, and 2000 general status reviews of wild species in Alberta (Alberta Fish and Wildlife 1985, 1991, Alberta Wildlife Management Division 1996, Alberta Sustainable Resource Development 2001).

This report summarizes historical and recent information on the brown creeper in Alberta, in an effort to update its status in the province.

\section{HABITAT}

The brown creeper uses different habitats for foraging, nesting, and during winter. These seasonal habitat preferences warrant more specific descriptions of important habitat

\footnotetext{
* See Appendix 1 for definitions of selected status designations.
}

variables (Conner 1980). To address these differences, habitat has been subdivided into the following categories: 1) general, 2) nesting, 3) foraging, and 4) wintering.

1. General. - In Alberta, general habitat descriptions suggest that brown creepers favour either mature or old-growth coniferous forests, or a combination of older, conifer-dominated mixedwood forests (Salt and Salt 1976, Scheick and Nietfeld 1995, McGillivray and Semenchuk 1998, Schieck et al. 2000). In Alberta, brown creepers also preferred older aspen forests with large, sparsely distributed trees, and high canopy heterogeneity based on a range of successional aspen forests (Schieck and Nietfeld 1995). Brown creeper abundance was also associated with trees $>20 \mathrm{~cm}$ (diameter at breast height, $\mathrm{dbh}$ ) and showed a strong positive relationship with the density of shrubs and saplings (Schieck and Nietfeld 1995). Near Calling Lake, Alberta, brown creeper abundance was positively correlated with the amount of older forest in the surrounding area and was negatively correlated with the amount of anthropogenic disturbance (F. Schmiegelow, unpubl. data). These two factors accounted for approximately $41 \%$ of the variation in brown creeper relative abundance. Hobson and Schieck (1999) compared the abundance of birds in post-fire and post-harvest habitats of 1, 14, and 28 years and found brown creepers in significantly higher densities in oneyear post-fire habitat than in either 14- or 28year post-fire or in all similarly aged post-harvest forests.

In the foothills region of Alberta, Farr (1995) found that brown creepers were associated with habitats containing old forest structure and relatively little deciduous understory cover. Brown creeper abundance also showed a positive linear relationship with increasing tree height, number of dead trees, percent of white spruce (Picea glauca), shrub height and shrub crown closure. Brown creepers showed a negative linear relationship between bird abundance and stand closure. In the mountain parks, brown 
creepers are more abundant in mature coniferous forest composed of Englemann spruce (Picea engelmannii)/fir, or lodgepole pine (Pinus contorta)/spruce (Holroyd and Van Tighem 1983).

In a study of burned older forest near Chip Lake, Alberta (see Recent Management in Alberta section), brown creepers appeared to utilize different habitat types throughout the year (C. Stambaugh, D. Stepnisky, and F. Schmiegelow, unpubl. data) (Figure 1). During the breeding season, brown creepers occurred in significantly greater abundance in burned, unharvested stands, than in unburned stands. This preference for burned, unharvested stands during the breeding season may be a result of increased nest site availability or food abundance in this habitat. Following fire, burned trees die quickly, causing bark to rupture and slough off, creating nesting and foraging microhabitats (C. Stambaugh and D. Stepnisky, pers. comm.) (see Nesting Habitat subsection below). In contrast, brown creepers occurred in significantly greater abundance in unburned, unharvested stands during the winter. During winter, older forested habitat may provide protection from both predators and the elements, while still providing a source of food and roost sites for brown creepers, whereas open, burned forest may not. Brown creepers were not detected in stands that were burned and salvage-logged ( $<20 \%$ snag retention) in either season.

In the boreal forest in general, brown creepers are described as preferring mature to old-growth conifer and mixedwood forests (Erskine 1977, Godfrey 1986, Kirk et al. 1996). In Saskatchewan, brown creepers preferred forests dominated by white spruce, followed by mixed forests, and lastly, aspen-dominated forests (Hobson and Bayne 2000a). In British Columbia, preferred habitat was described as old-growth forest, with fewer birds occurring in mature second-growth forest (Campbell et al. 1997). On Vancouver Island, British Columbia, brown creepers were recorded in $55 \%$ of 71 old- growth stands ( $>200$ years old) dominated by western red cedar (Thuja plicata) with some Douglas-fir (Pseudotsuga menziesii) and western hemlock (Tsuga heterophylla), but only in $19 \%$ of 36 younger stands (50 to 60 years old) dominated by Douglas-fir (Bryant et al. 1993).

In the northern Rocky Mountains, brown creepers occur at high density in mixed-conifer, lodgepole pine, spruce-fir, cedar-hemlock and ponderosa pine (Pinus ponderosa) forests (Hutto 1995). Brown creepers were also present, but at much lower abundance, in early successional burned, early successional clearcut and midsuccessional clearcut forests (Hutto 1995). In Washington, mature to old-growth Douglas-fir forest is preferred (Lundquist and Manuwal 1990). In Oregon, brown creeper abundance was also highest in old-growth Douglas-fir forests (Mannan et al. 1980, Hansen et al. 1995, Weikel and Hayes 1999), with significantly fewer birds detected in younger or fragmented forests (Hagar 1999, Hanula et al. 2000). In the western Cascade Mountains of Oregon, brown creeper abundance was highly correlated with attributes of older natural forests, such as large trees, large snags, and/or western hemlock ( $T$ suga heterophylla) (Hansen et al. 1995). In the north Coast Mountains of Oregon, brown creeper density increased in relation to the density of large trees (Weikel and Hayes 1999). In southeastern Alaska, brown creepers occurred exclusively in old-growth forests (Dellasala et al. 1996).

In the Great Lakes region, brown creeper abundance increased following fire, perhaps in response to the increase in available nesting sites in dead or dying trees (Apfelbaum and Haney 1981). In Minnesota, the density of brown creepers was high in recently burned forests and in older forests regenerating following fire (Apfelbaum and Haney 1977). In early successional forests (15 years following fire), brown creeper density was much lower. However, no information exists as to the 


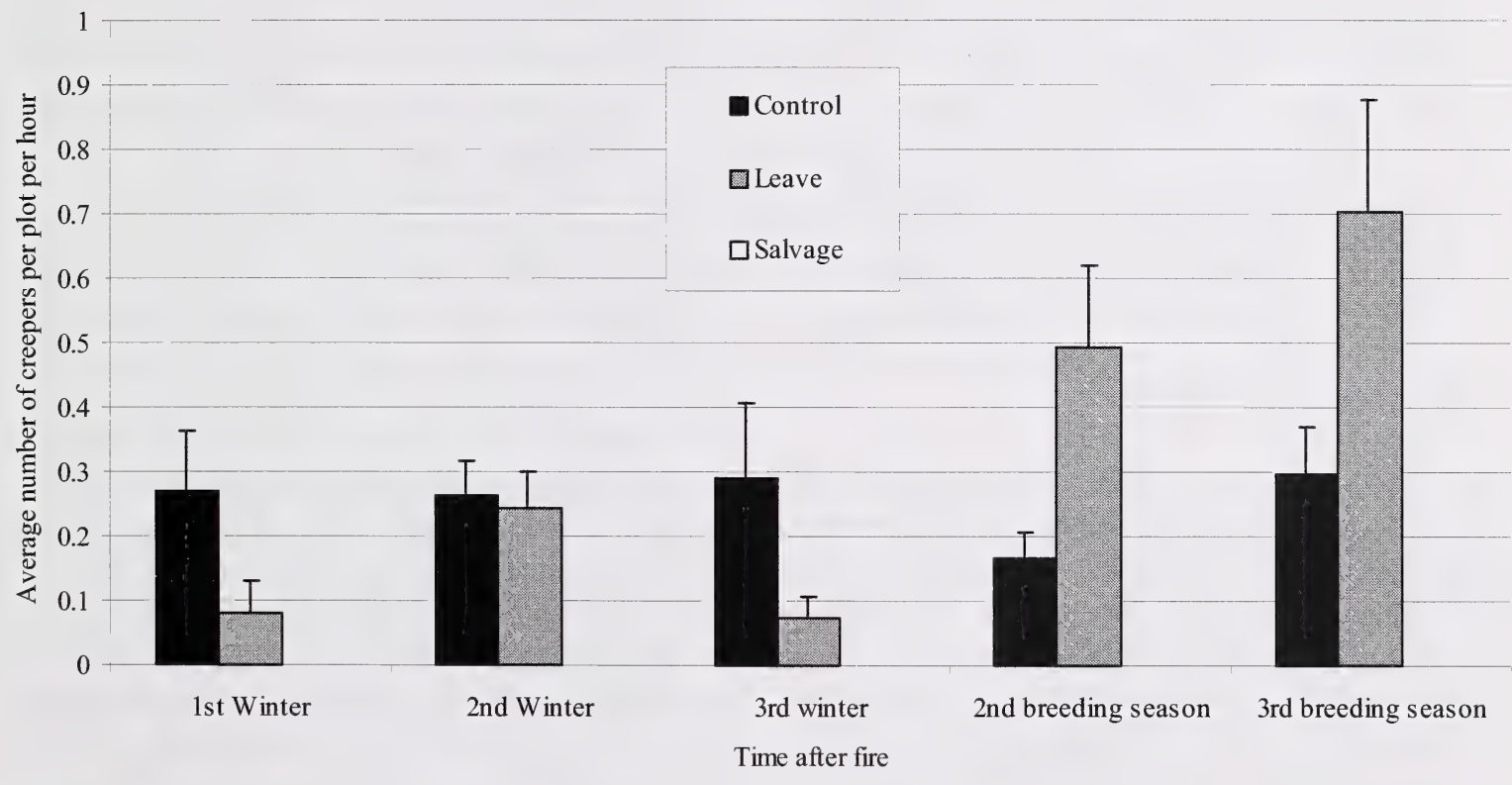

Figure 1. Comparisons of brown creeper abundance at several time intervals following fire near Chip Lake, Alberta. Winter period is from March to mid-April; breeding season is from early May through mid-July (D Stepnisky and F. K. A. Schmiegelow, unpubl. data). "Control" refers to unburned, unharvested, older deciduous-dominated forest; "Leave" refers to burned, unharvested, older deciduousdominated forest; "Salvage" refers to burned, harvested (salvaged), older deciduous-dominated forest (i.e., essentially no timber was left at salvaged sites). Brown creepers were not detected in stands that were burned and salvage-logged in either season. 
chronology of occupation of post-fire forests by brown creepers, especially between early regeneration and mature forest succession. In Quebec, brown creepers are restricted to mature forests (Shaffer and Alvo 1996) that are older than optimal cutting age (60 years) (Zarnowitz and Manuwal 1985), or recent burns (Imbeau et al. 1999). In the Appalachians, brown creepers use older, conifer-dominated forests in greater proportion to their availability on the landscape (Haney 1999). In Arizona, brown creepers also tend to prefer older coniferous and mixedwood forests, occurring in much higher densities in unlogged than logged forests (Franzreb and Ohmart 1978, Franzreb 1985). In the Sierra Nevada of California, Adams and Morrison (1993) found brown creeper abundance to be highly correlated with very large trees $(>100 \mathrm{~cm}$ $\mathrm{dbh}$ ) in old-growth stands.

2. Nesting. - To date, there have been no studies conducted in Alberta that have quantified brown creeper nesting habitat. Based on unpublished nesting records within the province, most appear to be in dead balsam poplar (Populus balsamifera $)(\mathrm{n}=5)$, followed by dead white spruce $(\mathrm{n}=3)$, and dead aspen $(\mathrm{n}=2)$ (Farr 1995, F. Schmiegelow, C. Stambaugh, D. Stepnisky, unpubl. data).

As a result of variation in fire intensity, tree mortality in post-fire habitats can be highly variable. This variability, in turn, can significantly affect the quality of post-fire habitat for brown creepers. Within two-year post-fire, unharvested forest near Chip Lake, Alberta, a significant negative relationship between burn intensity and brown creeper weighted abundance (weighted by behaviours associated with breeding activity/success - see Table 1) existed (C. Stambaugh and F. Schmiegelow, unpubl. data). However, in three-year post-fire habitat, a similar relationship was not observed, with brown creepers preferring forests of moderate burn intensity. Trees associated with high intensity burns tend to die quickly, resulting in the sloughing off of large quantities of bark.
Brown creepers nesting in these high intensity burn areas, where sloughing bark is very loose and unstable, tend to fail more often (C. Stambaugh, pers. comm.), thereby resulting in lower weighted abundance of brown creepers in this habitat. Snags in lightly burned or unburned forest, which have sloughing bark or natural cavities, may provide habitat in which brown creepers are more reproductively successful. In three-year post-fire forest, however, much of the bark on trees which were severely burned (high burn intensity) has already sloughed off, resulting in fewer nesting opportunities for brown creepers, and ultimately, reduced weighted abundance, although foraging opportunities may still exist. Trees in light to moderately burned forest may die off and slough bark more slowly, creating more suitable, longerterm breeding conditions for brown creepers, possibly resulting in higher weighted abundance. Given that the Chip Lake Burn Study was only initiated in 1998, preference of burned forest by brown creepers, beyond three years post-fire, have yet to be measured. However, given the results from the initial three years of data, low or medium intensity burns may be more valuable to brown creepers in the long term than high intensity burns, although these results are preliminary and require further investigation.

In British Columbia, most breeding records occurred in natural forest $(91 \%)$, as opposed to human-influenced ( $9 \%$ ) forest habitat (Campbell et al. 1997). The majority of nesting records (94\%) were south of $51^{\circ} \mathrm{N}$ latitude, with $68 \%$ of these records from the extreme southwest region of the province. However, this result may be a reflection of the distribution of the human population and a bias in survey effort more than the actual distribution of the brown creeper in the province. It is likely that the species is more widely distributed in the province above $51^{\circ} \mathrm{N}$ latitude.

In ponderosa pine and Douglas-fir forests of southwestern Idaho, brown creepers were recorded nesting in post-burn forest (Saab and 
Table 1. Abundance weightings for brown creeper observations (Modified from Schmiegelow et al. 1997).

\begin{tabular}{|l|c|}
\hline \multicolumn{1}{|c|}{ Behaviour } & Weight \\
\hline \hline Singing or countersinging male & 1.0 \\
\hline $\begin{array}{l}\text { Calling or observed male or } \\
\text { female }\end{array}$ & 0.5 \\
\hline Territorial dispute & 1.0 \\
\hline Pair observed & 2.0 \\
\hline Active nest observed & 2.0 \\
\hline Juvenile observed & 2.0 \\
\hline Adult carrying nesting material & 2.0 \\
\hline Adult carrying food & 2.0 \\
\hline Distraction display & 2.0 \\
\hline
\end{tabular}

Dudley 1998). In California, brown creepers nested in snags $(65 \%)$, dead portions of live trees (24\%), and live trees (12\%) (Raphael and White 1984). In Arizona, of five brown creeper nests, all were located in snags ( $\mathrm{Li}$ and Martin 1991). Of these nests, four $(80 \%)$ were in aspen and one $(20 \%)$ was in a conifer.

In addition to fires, brown creepers also seem to respond to many other forms of natural disturbance. Brown creepers are abundant in inundated areas, such as those created by beaver dams (Bent 1948, Davis 1978, K. Hannah, pers. obs.). Population expansion of the brown creeper in the states of Michigan and New York during the 1960s and 1970s was in response to outbreaks of Dutch elm disease (Ophiostoma novo-ulmi) (Davis 1978, Levine 1988). American elm (Ulmus americana) trees infected with Dutch elm disease were suitable for nesting when trees died and began to slough bark, creating abundant brown creeper nesting habitat. Use of this breeding habitat was short-lived, however, as trees with sloughing bark were only suitable until trees reached advanced stages of decay, after which incidences of nest failure were high (Davis 1978).
Given the unique nesting habitat requirements of the brown creeper (see Conservation Biology section), and its quick colonization of disturbed habitats, this species is likely limited by nestsite availability. This limitation remains true for most secondary cavity nesters and many bark-foraging species (Von Haartman 1956, Brawn and Balda 1988). The fact that brown creepers are known to roost and nest in artificial nesting structures illustrates this limitation (Bent 1948, Legg 1966, Merilees 1987). These nesting structures typically consist of slabs of bark, which are nailed on to the trunk of a tree, making a structure which closely resembles an actual brown creeper nest (see Campbell et al. 1997). It has been suggested that brown creeper populations could be enhanced by providing these structures in areas where foraging habitat exists, but nest sites are limited (Mannan et al. 1980). These artificial nest structures, however, would likely be inadequate in Alberta because of the remoteness of much of the boreal forest region (Imbeau et al. 2001). In addition, artificial nest structures would not provide a cost-effective option relative to other forest harvest and management options (McKenney and Lindenmayer 1994, Imbeau et al. 2001). 
3. Foraging. - No specific information on the foraging habitat of brown creepers exists for the province of Alberta. The brown creeper is a bark-foraging species that employs a peck-probe technique to capture prey. The prey typically consists of insect larvae and small invertebrates, which are found in the furrows of bark on the trunks of trees. The depth of bark furrows can vary by tree species and by the age of a tree (older trees generally having deeper bark furrows than younger ones). Given this relationship, brown creepers are more specialized to foraging site than most other, similar bark-foraging species (woodpeckers, nuthatches) (Wilson 1970).

In the Washington Cascades, brown creepers used Douglas-fir forests with trees $>50 \mathrm{~cm}$ (dbh) as foraging sites, disproportionately to their availability (Lundquist and Manuwal 1990). In Arizona, brown creepers selected taller trees with deeper, more numerous bark furrows in proportion to their availability (Franzreb 1985). As tree size increases, a corresponding increase in foraging area, foraging efficiency, and prey diversity occurs (Jackson 1979). Brown creepers also selected trees with a higher number of crown connections and a large number of dead branches (Franzreb 1985). The bark on these dead branches would slough, creating large fissures, and supporting greater numbers of invertebrate prey.

In Oregon, brown creepers foraged most often on live conifers (Weikel and Hayes 1999). In California, brown creepers foraged more often in live trees $(85 \%)$, than snags $(11 \%)$, or logs (4\%) in proportion to their availability (Raphael and White 1984). In Arizona, brown creepers foraged most often on the trunks of trees $(68.7 \%)$, but spent some time foraging on branches (30.4\%) (Franzreb 1985). In Oregon, brown creepers forage almost exclusively (98\%) on the bole (trunk) of the tree, spending more time foraging on the lower bole $(67 \%)$, than either the upper bole (19\%), or lower crown (14\%) (Weikel and Hayes 1999). In Minnesota, brown creepers varied their vertical foraging range in forests regenerating following fire (Apfelbaum and Haney 1977). Brown creepers foraged between $1 \mathrm{~m}$ and $3 \mathrm{~m}$ on trees in recent burns, between $1 \mathrm{~m}$ and $10 \mathrm{~m}$ in mature forest, and between $1 \mathrm{~m}$ and $15 \mathrm{~m}$ in old forest, irrespective of tree height. It is possible that bark furrow depth is greater at lower portions of the trunk, especially in younger trees, thereby resulting in greater foraging activity. As trees age, bark furrows may become deeper at greater height, thereby increasing the height at which brown creepers forage on the trunk of the tree.

4. Wintering. - During winter, brown creeper abundance is greatest at ecotones (transition area between two adjacent ecological communities), where structural complexity is highest (Root 1988). In Alberta, brown creepers occupy spruce forests along river courses, such as the Battle River, south of Camrose (Farley 1932). Recent studies suggest that some brown creepers do overwinter within their breeding range, although in much lower abundance than during the breeding season (F. Schmiegelow and D. Stepnisky, unpubl. data). Results from the Chip Lake Burn Study suggest that during winter, brown creeper abundance is significantly higher in unburned, mixedwood forests, than in either burned and salvage-logged, or burned and unharvested stands. The preference for unburned, unharvested stands in winter suggests that this habitat may support a greater abundance of food or offer greater protection from the elements and predation than do more open, burned forests (D. Stepnisky, pers. comm.), in contrast to the preference of burned, unharvested stands in summer.

\section{CONSERVATION BIOLOGY}

Female and male brown creepers are virtually identical in size $(17.8-20.3 \mathrm{~cm}$; Terres 1980), weight (7.2 - $9.9 \mathrm{~g}$; Dunning 1984), and plumage. Brown creepers have deep brown upperparts streaked with greyish white, becoming tawny on the rump and uppertail. The 
sides of the head are typically brown with a prominent whitish eyebrow line. The underparts are generally white and the undertail coverts and flanks are tinged buffy (Godfrey 1986).

Although few data exist on survival rates, a longevity record of four years and four months came from a banding recovery (Kennard 1975). This record suggests that the survival or longevity of brown creepers may be relatively low, especially when compared to similar species such as the red-breasted nuthatch (Sitta canadensis) (seven years and six months), the white breasted nuthatch (Sitta carolinensis) (nine years and nine months), and the black-capped chickadee (Poecile atricapillus) (12 years and five months) (Kennard 1975). For the brown creeper, however, banding in Canada has provided relatively little information on survivorship, migration routes or wintering areas. Only 13 birds were ever recovered from close to 25000 individuals that were banded in Canada between 1921-1995 (Brewer et al. 2000).

During all seasons, the call of the brown creeper consists of a high-pitched "seep" note, with a pitch similar to the golden-crowned kinglet (Regulus satrapa) (Godfrey 1986). It is this similarity that often leads to confusion in the proper identification of the brown creeper in the field, potentially resulting in an underestimation of the occurrence of this species in many surveys. The song of the brown creeper, typically heard in spring and occasionally on warm days in autumn, consists of three short, wiry, highpitched, rolling warbler-like phrases, preceded by a single, slightly longer, shriller note (Godfrey 1986).

When foraging, brown creepers start near the bottom of a tree, moving up and around the trunk with a series of jerky hops (Davis 1978). Individual brown creepers typically forage up to within 1-3 m of the top of the tree, then fly to the trunk of a nearby tree, or drop to a lower level on the same tree (Davis 1978, Franzreb 1985). This behaviour may vary with tree species as brown creepers tend to forage upwards until increasing branch density within the crown of a foraging tree impairs manoeuvrability (Franzreb 1985). Unlike most other members of the bark-foraging guild in North America, brown creepers do not disturb the bark of the host tree when foraging. Using their long, decurved bill, curved claws, long toes, short legs, and long tail, the brown creeper is perfectly adapted for picking food from cracks and crevices on the bark surface (Franzreb 1985). Brown creepers typically employ a peck-probe method of foraging $(92.5 \%)$, followed by gleaning $(6.9 \%)$, and least often hawking $(0.6 \%)$ (Franzreb 1985).

During the breeding season, the diet of the brown creeper consists of insect larvae, pupae, and eggs. Spiders, along with other small invertebrates and seeds are also occasionally consumed (Pearson 1923). The diet of the brown creeper was previously thought to consist primarily of soft-bodied arthropods (Franzreb 1985). In a more recent study, however, both soft- and hard-bodied arthropods were present in brown creeper digestive tracts, suggesting that their rather thin and delicate bill morphology may not limit the use of certain food items (Mariani and Manuwal 1990). According to Erskine (1977), Coleoptera (beetles) comprise the largest portion of the diet in brown creepers. Alternatively, Martin et al. (1951) suggest that Araneida (spiders) comprise a major food source for brown creepers. . Spiders contain a higher protein content relative to insects (Hurst and Poe 1985), thereby providing a premium food source for brown creepers (Norberg 1986).

During winter, in upland deciduous forests of central Illinois, the diet of the brown creeper consisted primarily of insects (92\%) (Williams and Batzli 1979). Of these insects, Homoptera (aphids, leafhoppers, cicadas) constituted the largest proportion (34.4\%), followed by Hemiptera (true bugs) $(22.8 \%$ ), adult coleoptera (12.4\%), and Araneida (11.6\%); and some vegetable matter $(8 \%)$, including very small 
quantities of corn and acorns. In winter, brown creepers have also been known to visit bird feeders for sunflower seeds and suet, and are known to cache food (Lima and Lee 1993). Outside of the breeding season, brown creepers frequently forage in mixed-species flocks formed around chickadees (Poecile spp.) (Morse 1970), nuthatches (Sitta spp.), kinglets (Regulus spp.), and small woodpeckers (Picoides spp.) (Bent 1948). Within these mixed-species feeding flocks, brown creepers rely more heavily on insects in their diet than do other species (Bent 1948, Williams and Batzli 1979).

Arthropods, the primary prey of brown creepers, tend to vary in response to the suitability of microclimatic conditions created by bark structure, which affects both the diversity and abundance of this prey (Jackson 1979). In many studies, significant positive correlation between bark furrow depth and arthropod abundance indicate the importance of larger, older trees to many bark-foraging species (Raphael and White 1984, Mariani and Manuwal 1990, Hooper 1996, Hanula et al. 2000). As a result of high food availability, brown creepers tend to forage for longer periods of time on larger trees than on smaller ones (Lundquist and Manuwal 1990). Bark structure, however, differs both within and between tree species depending on size and age (Jackson 1979). Therefore, optimal foraging trees may be regionally specific with respect to tree species and age.

Given the specific foraging strategy and habitat requirements of the brown creeper, variation in prey abundance and availability, even at the stand level, may influence the presence of this species. Franzreb (1985) suggested that there might be a threshold number of foraging sites (trees) in an area to make it suitable habitat for brown creepers, whereas resource density below this level is not acceptable. Although no specific values are given, such a threshold would again be highly variable regionally with respect to tree species, age, and density. Although tree density may seem highly important, tree size may be more important to brown creepers, since foraging by brown creepers is energetically costly (Norberg 1986). To emphasize this tradeoff, Mariani and Manuwal (1990) estimated that, based on bark surface area of Douglas-fir trees, brown creepers would have to forage on 13 young trees ( $29 \mathrm{~cm} \mathrm{dbh}), 3.3$ mature $(67 \mathrm{~cm} \mathrm{dbh})$, or one old-growth tree $(112 \mathrm{~cm} \mathrm{dbh})$ to obtain a similar amount of food in the Washington Cascades. This rather simple comparison greatly emphasizes the magnitude of the trade-off between tree size and foraging efficiency in this species and the value of maintaining large, old trees within a stand.

For nesting, the brown creeper uses a niche that is unique to all other North American passerine birds. Brown creeper nests are usually well concealed between cracks in tree bark or behind loose pieces of bark that have pulled away from dead or dying trees (Salt and Salt 1976, Davis 1978, Holroyd and Van Tighem 1983). Occasionally, brown creepers will use abandoned woodpecker holes or natural cavities in trees (Bent 1948, Salt and Salt 1976), although brown creepers are not dependent on cavities (Raphael and White 1984). Nests are usually located relatively low on the trunk of the tree, between $1 \mathrm{~m}$ and $15 \mathrm{~m}$ (Erlich et al. 1988, Semenchuk 1992). In British Columbia, the heights of 43 nests ranged from $0.2 \mathrm{~m}$ to $15 \mathrm{~m}$, with $58 \%$ between $2.2 \mathrm{~m}$ and $6.0 \mathrm{~m}$ (Campbell et al. 1997). Of 32 nests from various locations, nest height ranged from $1.3 \mathrm{~m}$ to $9 \mathrm{~m}$, with $68 \%$ between $1.3 \mathrm{~m}$ and $4.3 \mathrm{~m}$. Average tree size was $30.4 \mathrm{~cm}$ (dbh) with a range from $15 \mathrm{~cm}$ to $67.5 \mathrm{~cm}$ (Davis 1978, Raphael and White 1984, Li and Martin 1991, Farr 1995, F. Schmiegelow, D. Stepnisky, and C. Stambaugh, unpubl. data).

The nest itself is an untidy, crescent-shaped structure of roots, moss, and grass on a base of twigs (Baicich and Harrison 1997). A cupshaped depression at the centre of the nest is lined with feathers and bark shreds (Baicich and Harrison 1997). The female typically constructs nests within six to seven days, with help from 
the male (Baicich and Harrison 1997). Clutches consist of four to eight (typically five to six) whitish eggs, marked with reddish brown (Salt and Salt 1976, Godfrey 1986, Erlich et al. 1988). An unusually large clutch of 12 eggs from a nest in British Columbia was likely laid by more than one female (Campbell et al. 1997), although intraspecific brood parasitism or co-operative breeding has not been documented in this species. Incubation lasts between 14 and 15 days, and males feed females on the nest during this time (Baicich and Harrison 1997). The young are tended by both parents for 14-17 days prior to fledging (Baicich and Harrison 1997). It is not known whether this species doublebroods (Davis 1978, Erlich et al. 1988). Birds are reproductively mature after one year (DeGraaf and Rudis 1987), and are monogamous (Erlich et al. 1988).

A total of 11 out of $19(58 \%)$ nests produced at least one fledgling in a study from Michigan (Davis 1978). In British Columbia, from three nests followed to known fate, two produced at least one young. In a study conducted in a recent burn in central Alberta, from five nests, one nest produced at least one young (C. Stambaugh, D. Stepnisky, unpubl. data). The largest single cause of nest failure appears to be from weather damage, with upwards of $60 \%$ of failed nests a result of wind or rain damage (Davis 1978). This damage may be nest-tree specific, since bark may slough and detach from trees differently depending on tree species. This problem may be more specific to geographic or physiographic region, or to the cause of tree mortality (fire or flooding, etc.). In the Chip Lake study, several nests located in burned trees also failed as a result of weak and sloughing bark detaching from trees prior to the completion of nesting (C. Stambaugh and D. Stepnisky, pers. comm.).

\section{DISTRIBUTION}

1. Alberta. - The brown creeper occurs throughout most of the forested regions of the province (Figure 2). Recorded north of Fort McMurray and as far south as Waterton Lakes National Park, this species occurs in five of six natural regions of the province (see Alberta Natural Heritage Information Centre 2002a). The northern limits of this species within the province are unknown, but extend to Winagami Lake and the Peace River district (Salt and Salt 1976). To the south and west, brown creepers range through Athabasca, Edmonton, Pigeon Lake, Calgary, and into the Rocky Mountains (Salt and Salt 1976).

2. Other Areas. - The brown creeper is considered a resident species in the Queen Charlotte Islands, in the mountains of southeast Arizona and southwest New Mexico, south to Nicaragua, and in most of northeastern North America, including the Great Lakes, Appalachian Mountains, and upper Mississippi River valley (American Ornithologists' Union 1998, Sauer et al. 2001) (Figure 3).

As a breeding species, brown creepers range from south-central Alaska, across Canada, to south-central Quebec and Newfoundland. It occurs in the Appalachians south to western North Carolina and eastern Tennessee, and in the lowlands of Virginia, Maryland and Delaware. The species also occurs in West Virginia, southern Ontario, southern Michigan, central Ohio, southern Illinois, southern Iowa, and from southeastern Missouri to southeastern Nebraska (American Ornithologists' Union 1998). In the southwest, it breeds from western Texas to central and southeastern Arizona. Brown creepers also breed in southern Nevada and southern California, and in the mountains of Middle America, through Mexico, Guatemala, Honduras and into north-central Nicaragua (American Ornithologists' Union 1998).

During the nonbreeding season brown creepers range from southern, coastal Alaska and southern Canada, south throughout its breeding range, except at higher latitudes and elevations. Brown creepers also occur in southern Texas, 


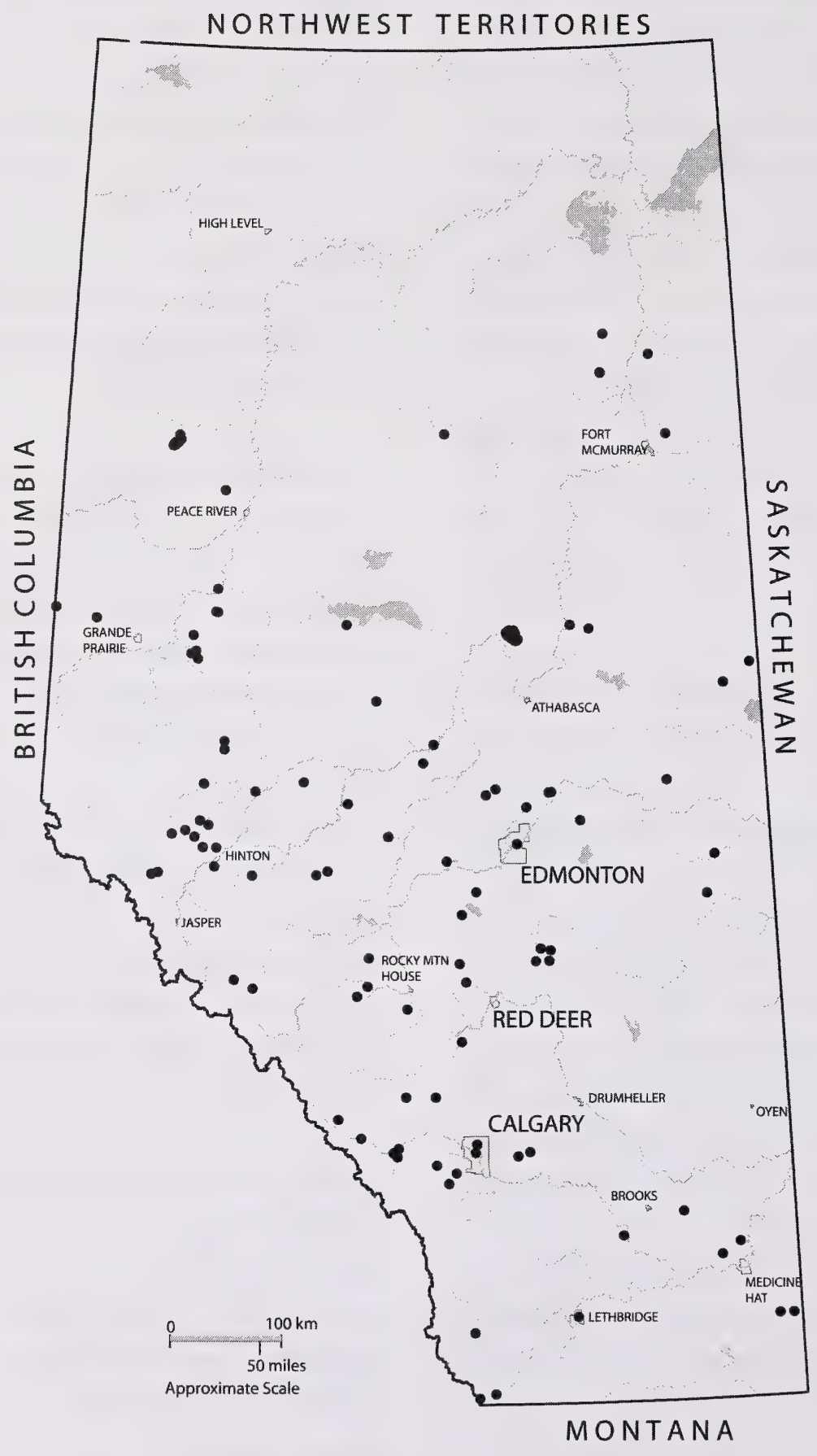

Figure 2. Distribution of the brown creeper in Alberta. Details of these records can be found in the Biodiversity/Species Observation Database (BSOD) maintained by Alberta Sustainable Resource Development. 


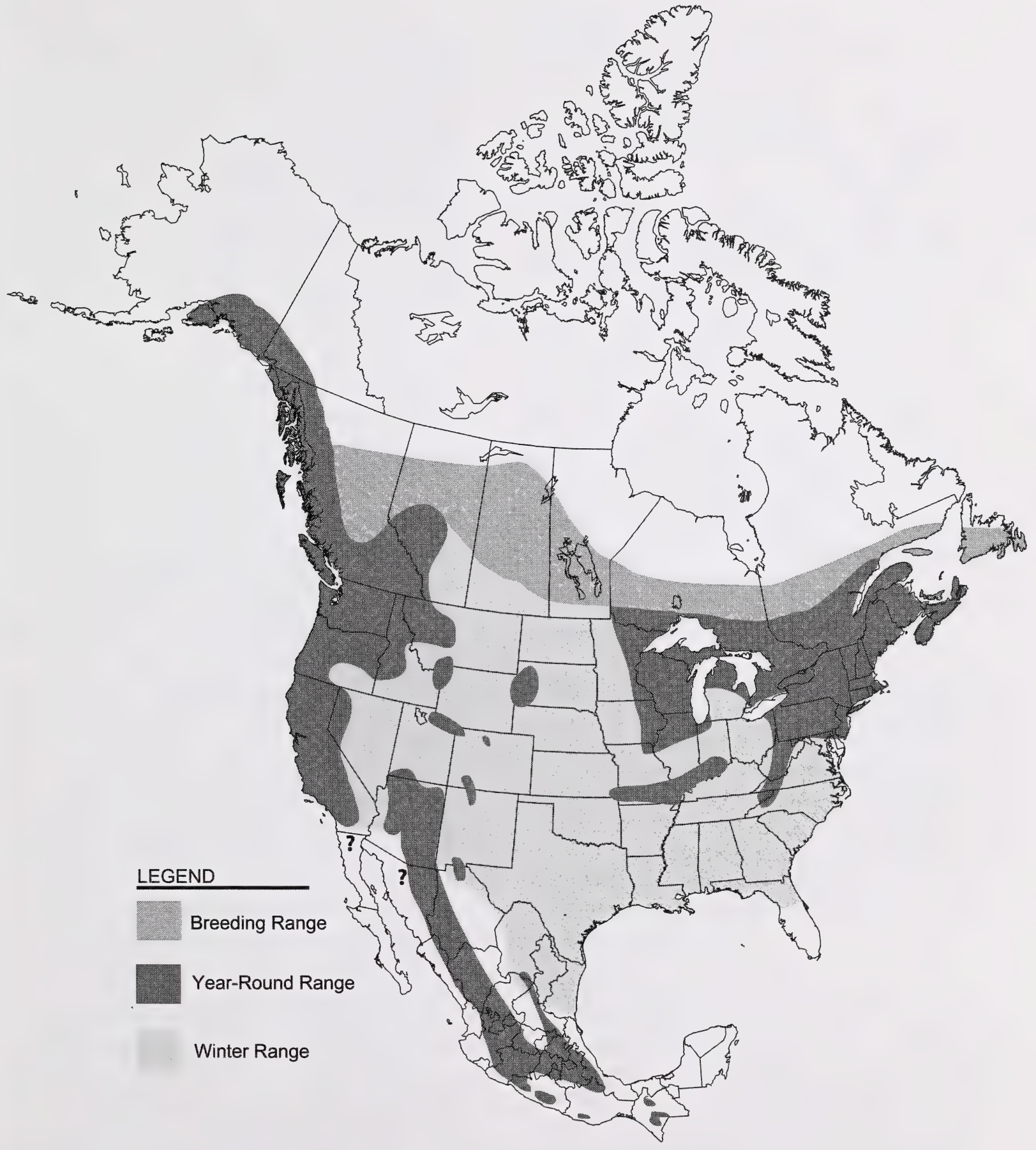

Figure 3. Breeding, resident (year-round), and wintering ranges of the brown creeper in North America and Central America (adapted from American Ornithologists' Union 1998, Sauer et al. 2001, and Howell and Webb 1995). 
along the Gulf Coast, and in northern Florida. During the nonbreeding season, the brown creeper is also a regular inhabitant in the lowlands of the western United States and northern Mexico (American Ornithologists' Union 1998).

Reforestation in the northeastern United States, especially New York state, has undoubtedly restored additional brown creeper habitat, resulting in a southern extension in breeding range between the 1960s and 1980s (Levine 1988). Also during this period, a southern range expansion in Michigan (Davis 1978), and dramatic increase in abundance in central New York state was attributed to the spread of Dutch elm disease (Rusk and Scheider 1966, Scheider 1971). A small population of brown creepers was recorded on the island of Bermuda around 1870 (Bent 1948).

\section{POPULATION SIZE AND TRENDS}

1. Alberta. - There are no specific population size estimates for the brown creeper in Alberta. Given that the species is sometimes overlooked, existing research and surveys conducted within the province may not reflect the actual population size. This is especially true of historical accounts in the province, where the species is suggested as being uncommon or scarce (Macoun and Macoun 1909, Farley 1932). As numbers of observers have increased in recent decades, especially in more remote areas of the province, so too have records of breeding locations and other distributional data for this species. In the five years of data collected for the Alberta Breeding Bird Atlas Project (19871991), there were only eight confirmed breeding records for the brown creeper (Semenchuk 1992). However, with probable breeding by this species in five of the six natural regions in the province, both abundance and distribution are probably higher than previously thought. However, brown creepers are still far less common than most other passerine songbirds breeding in the province. In older, aspendominated forests near Calling Lake, Alberta, the brown creeper was ranked 21 out of 59 species of breeding songbirds, based on abundance (Schmiegelow 1997). Because of the relative scarcity or difficulty in detecting this species, it has only been recorded on two Breeding Bird Survey (BBS) routes within the province (Sauer et al. 2001). As a result, there is no reliable trend information for this species in Alberta.

2. Other Areas. - There are no estimates of population size for the brown creeper in any area of its breeding range. Estimates of breeding density suggest, however, that across most of its range, brown creeper density is relatively low. In an old white cedar (Thuja occidentalis) swamp in Michigan, brown creeper density ranged from 0.16 to 0.44 birds per hectare $(n=20)$ (Davis 1978); in Quebec, Cyr (1974) estimated density at 2.15 birds per hectare in a hemlock stand; and in Ontario, Kendeigh (1947) estimated the density at 1.0 bird per hectare in a coniferous forest dominated by fir, black spruce, and white spruce.

Based on Canada-wide BBS data, brown creeper populations have increased by approximately $7 \%(p=0.01)$ between 1966 and 1996 (Sauer et al. 2001) (Figure 4). Within the Closed Boreal Forest Region, which includes a portion of the range of the brown creeper in Alberta, populations have increased significantly by $12.5 \%(p=0.001)$ since 1966 . The only statistically significant declines are from the Cascade Mountains of central Washington, with a decline of $6.9 \%(p=0.03)$ since 1966 . However, most survey regions have too few brown creeper detections to establish both biologically and statistically meaningful trends from BBS data. Therefore, with the exception of a few populations, trend information across North America is sparse. 


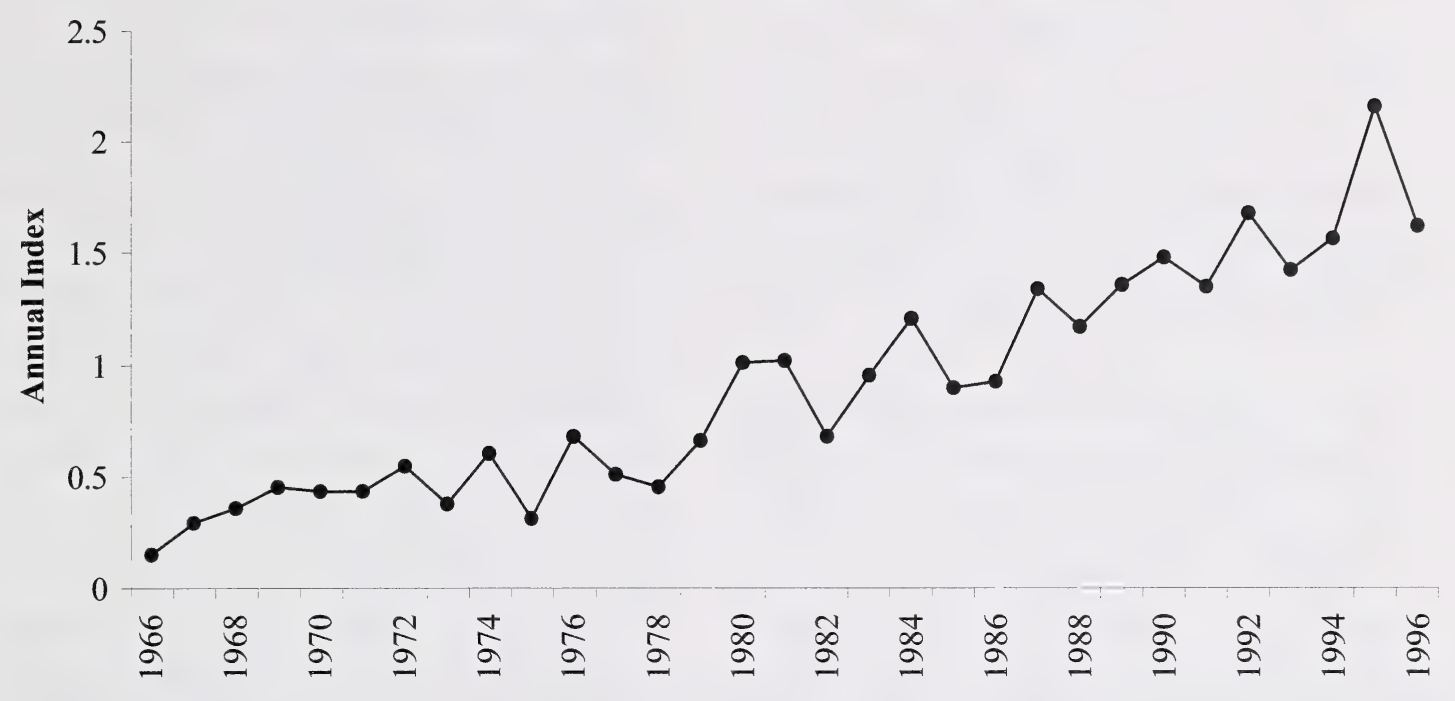

Figure 4. Trends in the population of the brown creeper in Canada, 1966-1996. Data source is the Breeding Bird Survey (BBS) (modified from Sauer et al. 2001).

\section{LIMITING FACTORS}

1. Habitat Loss and Fragmentation. - In recent decades, declines in many passerine songbirds have been linked to increased habitat fragmentation (Hagan and Johnston 1992). Although highly debated, the most likely causal explanation for the decline of many North American passerine birds species has been a loss of forest habitat throughout their breeding ranges (Böhning-Gaese et al. 1993, Sherry and Holmes 1993, Robinson and Wilcove 1994). Harvesting and fragmentation of forest habitat can result in an increased amount of edge (Whitcomb et al. 1981, Yahner 1988), reductions in the amount of high-quality, interior forest habitat (Rich et al. 1994), changes in vegetation structure (Ranney et al. 1981, Fraver 1994), and the further degradation and isolation of remaining habitat (Robinson et al. 1995).

The forested regions of Alberta have seen an enormous increase in recent industrial development, prompting concern for some bird populations in the province. Within the last decade, the majority of the province's forested lands have been leased to forestry companies with little or no prior knowledge of most of the bird species in the region (Schmiegelow and Hannon 1993). This lack of data has spawned a growing interest in forest harvest and fragmentation studies within the province in the past decade.

Results of several studies conducted in Alberta in recent years suggest brown creepers are immediately and negatively affected by forestry activities (Farr 1995, Schmiegelow 1997, Tittler 1998). Given this species' dependence on older forests, it is clear that recently harvested clearcuts and early successional, regenerating forests do not support this species (Hobson and Scheick 1999, Scheick et al. 2000), at least until sufficient regeneration has occurred (40-80 years post-harvest) (Kirk et al. 1996). Even partialcut harvesting of 130 year-old, aspen-dominated 
mixedwood stands, with $11 \%-39 \%$ residual retention, did not support brown creeper populations (Tittler 1998). Brown creepers were detected in logged sites immediately following harvesting (Norton and Hannon 1997), but were not detected three years later. Individuals may have settled in sub-optimal habitat (partial cuts) initially, and then, following poor breeding success, emigrated to other areas.

In Oregon, brown creepers were more abundant in unlogged than logged riparian buffer strips, with abundance increasing in relation to buffer width (Hagar 1999). In Vermont, Germaine et al. (1997), found brown creepers to be significantly less abundant near openings than in the forest interior. In Wyoming, brown creepers were also absent from both strip-cut and spot-cut stands compared to unfragmented tracts of subalpine forest (Keller and Anderson 1992). In Arizona, brown creepers were also more abundant in unlogged, mixed-coniferous forests, than in similar, logged forests (Franzreb and Ohmart 1978).

Brown creepers also appear to be sensitive to both natural and human-induced fragmentation. In Calling Lake, brown creepers were detected in only the largest stands ( $\geq 54$ ha) of isolated, older, aspen-dominated forests, surrounded by black spruce (Picea mariana) forests (Schmiegelow 1997). Brown creepers appeared to show a patch size effect, and their abundance was positively correlated with fragment size (Spearman's correlation coefficient 0.552 , $p=0.06$ ) (F. Schmiegelow, unpubl. data). In general, brown creepers were also less abundant in forest fragments surrounded by clearcuts, than in continuous, unharvested forest near Calling Lake, Alberta (F. Schmiegelow, unpubl. data) (Figure 5). However, variation in this relatively rare species over time makes the magnitude of fragmentation effects difficult to assess. In Saskatchewan, Hobson and Bayne (2000b) found that brown creepers occupied only the largest habitat fragments in an agricultural matrix.
A proactive approach to measuring the relative sensitivity of North American bird species to forest harvest and fragmentation may be to compare changes in forest bird communities in Europe, where forests have been harvested and fragmented for much longer. Regional variation in levels of forest fragmentation may also lead to variation in the reproductive success of forest songbirds. However, as long as enough high quality habitat is available across the entire range of a species to maintain a surplus of young birds each year, areas of low productivity and high fragmentation could maintain a species regionally, even in poor quality habitat, as long as levels of immigration are high. Over a considerable time-lag, as more of the range becomes fragmented, overall productivity drops, immigration declines, and correspondingly, a species begins to decline. This time-lag suggests that declines may not emerge immediately after the forest is harvested and fragmented, and may take upwards of several decades to be detected (Imbeau et al. 2001). For example, in Finnish forests, extensive harvesting of both mature and old forests caused dramatic reductions in Eurasian treecreeper (Certhia familiaris) populations, but only after several decades (Helle and Järvinen 1986). Based on the brown creeper's unique life-history traits and strong dependence on older, coniferous forest, it is likely to be negatively impacted by modern forestry practices in North America in the future (Imbeau et al. 2001).

Finally, clearcutting is known to increase windspeed as a result of opening up the forest (Navratil 1994). Increased wind may result in the loss of large sections of sloughing bark, which is required by brown creepers for nesting, thereby increasing rates of nest failure. To reduce wind speed and subsequent winddamage, forest managers should do the following: i) make successive clearcuts proceed against the wind, ii) make cuts in narrow strips of a maximum of 20-100 m, and iii) orient these strips at right angles to the prevailing wind direction (Navratil 1994). 


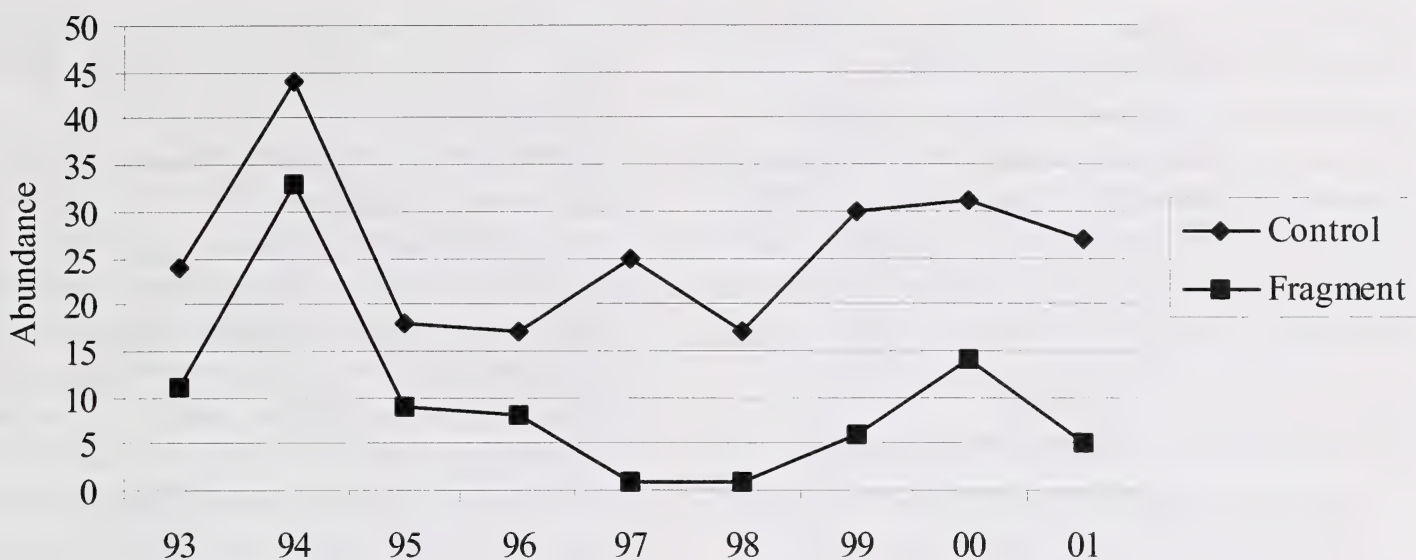

Year

Figure 5. Brown creeper abundance in mixedwood forest near Calling Lake, Alberta between 1993 and 2001. Control refers to continuous, unfragmented forest, and fragment refers to patches of forest habitat surrounded by 200-m wide clearcuts. Fragmentation in winter of 1993 reflected in "crowding effect" in 1994, and variability in abundance between 1994 and 2001 (F. K. A. Schmiegelow, unpubl. data).

2. Fire Suppression. - In the western boreal forest, fire has played the most significant role in shaping the landscape. As a result, many species are partially or wholly dependent on this form of natural disturbance. For instance, numerous bird species appear to converge on recently burned forests to take advantage of newly created nesting sites and an increased food supply. These species include black-backed (Picoides arcticus) and three-toed woodpeckers (P. tridactylus), house wrens (Troglodytes aedon), mountain bluebirds (Sialia currucoides), and northern hawk owls (Surnia ulula) (Hutto 1995, Hobson and Scheick 1999, Hoyt 2000, K. Hannah and J. Hoyt, in review.). Although the brown creeper is not dependent on post-fire habitat for breeding or foraging, it does occur in this habitat in relatively high abundance (see Habitat section).

With the potential for wildfire to destroy both economically valuable timber and other private and public property, the province of Alberta has adopted an intensive fire suppression policy (see
Cumming 1997). Although fire suppression may be an effective way to manage economically valuable timber resources, it does not permit management of non-timber values, such as retention of fire-adapted or fire-dependent species. For many of these species, the significance of these post-fire habitats is poorly understood. In particular, data on rates of reproductive success, prey abundance and accessibility, and survival in post-fire forests do not exist. Without this information it is difficult to recommend practices that may benefit these species. A proactive approach to managing species that may benefit from post-fire habitat would be to encourage the maintenance of this habitat on the landscape. This approach would include maintaining post-fire habitat at several spatial and temporal scales to maximize the benefits to a variety of species. If fire suppression is continued in the province of Alberta and some small to medium fires are not allowed to burn, management of species that use post-fire habitats may require prescribed burning (Hutto 1995, Hoyt 2000). 
3. Salvage Logging. - Following wildfire, the economic losses of merchantable timber can sometimes be large. With additional economic losses in post-fire habitats from both woodboring and bark-boring insects, which quickly colonize dead and dying trees, and from winddamage and blow-down, forest managers tend to remove remaining timber from burned forests as quickly as possible (Sampson et al. 1985).

Fires in the western boreal forest tend to be dynamic, varying greatly in their intensity, speed and direction of movement (Rowe and Scotter 1973, Cumming 1997). As a result, within larger burns, areas of unburned timber or "skips" tend to remain following wildfire. This dynamic mosaic of burned and unburned forest may provide an essential mixture of habitats to certain species, including the brown creeper (see Habitat section). Salvage logging operations tend to harvest all merchantable timber following fire, regardless of burn intensity. Little or no structure is retained following salvage logging, reducing or eliminating the ecological or non-timber value of this unique habitat.

Salvage logging may be a lesser problem in larger fires where burned timber cannot be entirely salvaged prior to losing its economic value from insects, disease and desiccation. Salvage logging in the more frequent, smaller fires, may be more of a problem because all of the burned timber can be removed in a short period of time (Hoyt 2000). In this regard, salvage logging practices could allow for the management of fire-adapted and fire-dependent species, especially in smaller, less intense fires, and simultaneously allow for economic benefits of timber harvest. In particular, delaying salvage logging by at least one breeding season may be beneficial (Hutto 1995, Murphy and Lehnhausen 1998) without causing excessive damage and economic losses to merchantable timber.

4. Forest Management. - Forest harvesting has increased dramatically in the province of Alberta in recent years. Of particular concern is the prioritized harvest of older forests first (Alberta Environmental Protection 1994). With a projected stand rotation age of 60-80 years in Alberta, brown creeper habitat will shrink dramatically (Erskine 1977). Coupled with intensive fire prevention and suppression activities, reductions in preferred brown creeper habitat will likely be substantial. Ideally, the most beneficial management strategy includes extending harvesting rotations so that older-aged forests are maintained on the landscape. Alternatively, the retention of large, intact blocks of older, mixedwood and conifer-dominated stands in a reserve system may be a desirable management strategy.

Following forest harvest, standard practice in Alberta favours the re-planting of either conifer or deciduous dominated forests. This ultimately results in the "unmixing" of mixedwood forests (Hobson and Bayne 2000a) with possible negative implications for the brown creeper, given its apparent preference for this habitat (see Habitat section). Naturally, a mixedwood forest takes much longer than the 60-80 year rotation period to develop (Lee et al. 1995). Most forests regenerate with aspen trees in the canopy and only after mature aspen forests begin selfthinning after 70-90 years does white spruce begin to emerge as a canopy species. Over time, naturally occurring mixedwood forests will become more scarce on the landscape, thereby providing less habitat for brown creepers given their unique foraging and nesting requirements.

In addition to breeding habitat, brown creepers appear to use areas of mixedwood forests with high structural heterogeneity during winter. This may be even more of a management concern in more southern forested areas of the province, where both access and economic viability will mean these forests will be harvested first. It is in these more southern forested areas where many brown creepers in the province overwinter (Root 1988). Therefore, the creation or regeneration of mixedwood forests in the province, following suitable guidelines, could 
be expected to benefit brown creepers over the long term.

5. Energy Sector Activities. - With increased oil and gas development in Alberta, forested regions are impacted and habitat is lost through the creation of numerous seismic lines, pipelines, and wellheads. Although these losses cover less area than the amounts harvested annually by forestry companies within the province (see Norton 1997), the ecological losses may be great. Because of the linear nature of both seismic lines and pipelines, the increased edge-to-interior ratio may favour increased nest predation, parasitism, or both. In addition, large linear corridors may increase wind speed, which may also result in greater losses of brown creeper nests and potential nesting sites as a result of wind damage.

6. Agriculture. - Agriculture, unlike many other forms of land-use in the province of Alberta, permanently removes large areas of forested land from the landscape. Although agriculture is reaching its northern limit within the province, large areas of forest are converted to agriculture every year. Although traditional agricultural practices themselves do not pose much of a threat to this species, the most significant impact is the direct loss of forested habitat. According to Bayne and Hobson (2000), brown creepers avoid smaller woodlots surrounding agricultural areas. Therefore, to further enhance habitat for brown creepers in agricultural areas, it may be beneficial to encourage the retention of larger remnant woodlots. In this regard, the minimum threshold size of woodlot necessary to support brown creepers would need to be established.

\section{Parasitism and Predation. - In eastern North} America, high rates of nest parasitism and predation are thought to limit songbird populations (Andrén 1992, Robinson et al. 1995). However, only three published occurrences of brown-headed cowbird (Molothus ater) parasitism on brown creepers exist (Friedmann and Kiff 1985). In British Columbia, of 37 brown creeper nests monitored from the incubation stage, none were parasitized by cowbirds (Campbell et al. 1997). With such a small sample of brown creeper nests, however, published records may not be representative of the range in geographical variation of both the abundance of brown creepers and brown-headed cowbirds, and the degree of fragmentation on the landscape. Brown-headed cowbird parasitism may pose more of a problem in more patchy landscapes, such as those in forestrydominated or agricultural landscapes where cowbird abundance is higher.

Given the cryptic plumage of this species and its ability to conceal itself from predators against the bark of trees (Bent 1948, Davis 1978), rates of adult predation are likely low. However, because of the placement of nests (relatively low on the trunks of trees), nest predation rates may be relatively high. Although very little data exist on predation rates in this species, rates of nest success are comparatively low (see Conservation Biology section). Further investigation into the causes of nest failure for this species within the province is needed.

\section{Winter and Migratory Stop-over Habitat. -} Many studies implicate habitat loss on the breeding grounds as a major cause of population declines for passerines in North America; however, there may also be other, equally important considerations throughout the year. Direct loss of habitat on the wintering grounds may also be responsible for population declines in many species (Sherry and Holmes 1993) and these factors may be more significant than those on the breeding grounds (Rappole and McDonald 1994, Sherry and Holmes 1996).

Although brown creepers are resident in the province, with a small portion of the population overwintering (Semenchuk 1992, Schmiegelow, unpubl. data), the southward movement of brown creepers into alternative habitat in winter does pose additional management considerations. The apparent preference for older spruce forests along river valleys and forest 
ecotones in winter may be more difficult to manage for (see Habitat section). This may be ameliorated somewhat in the mountain parks, with the greatest abundance of overwintering brown creepers occurring between Waterton Lakes/Glacier International Park (Root 1988), where habitat is more secure.

Little is known about the seasonal movements of the brown creeper within the province. In particular, little information exists on the duration, routes, and demography of these seasonal movements. Better information on postbreeding dispersal, seasonal movements, and ecology/habitat preferences on the wintering grounds would be beneficial.

\section{Human Disturbance. - Brown creepers} appear to be sensitive to direct human disturbance, especially when nesting. In Michigan, Davis (1978) found that brown creepers were quick to abandon nests when repeatedly disturbed by human observers. A female brown creeper that was captured, banded, and then flushed from her nest on the same day, failed to return. Because of the difficulty in gaining access to nests, use of a ladder on the nest tree can also increase nest abandonment (Davis 1978). Repeated nest checks may damage the nest because of the frailty of the nest structure, resulting in loss of the nest or abandonment (Bent 1948, Shaffer and Alvo 1996). In Alberta, of five nests that were monitored throughout the breeding season, no evidence of human-induced nest abandonment was recorded (D. Stepnisky and C. Stambaugh, pers. comm.). Although additional work on almost every aspect of the breeding biology of brown creepers is necessary, caution should be exercised when undertaking such studies so as not to cause excessive disturbance to the species during nesting and breeding.

\section{STATUS DESIGNATIONS*}

1. Alberta. - The brown creeper was listed as status "Undetermined" in the 1985, 1991, 1996, and 2000 reviews of the general status of wildlife in Alberta (Alberta Fish and Wildlife 1985, 1991, Alberta Wildlife Management Division 1996, Alberta Sustainable Resource Development 2001). This designation is largely a result of the lack of published data dealing with almost every aspect of this species' natural history. In Alberta, the brown creeper has been given a ranking of S3S4 (Alberta Natural Heritage Information Centre 2003), as the species is rare or local throughout its range and is susceptible to extirpation because of largescale disturbances. Consequently, the brown creeper is presently on the Alberta Natural Heritage Information Centre's Tracking list, based on potential concern over breeding populations (Alberta Natural Heritage Information Centre 2003).

As part of a national management and conservation priority-setting exercise, the brown creeper was ranked 105 out of 232 landbird species in Alberta in terms of "provincial supervisory responsibility" (Dunn 1997). This ranking was based on a combination of the extent of this species' range in the province and potential threats to its persistence.

2. Other Areas. - The brown creeper has not been considered by the Committee on the Status of Endangered Wildlife in Canada (COSEWIC 2001). Based on assessments by the Natural Heritage Program, which assesses the conservation status of all species and ecosystems, the brown creeper has been given a global rank of G5 (NatureServe Explorer 2001). This is largely because the species is widespread, reasonably common, and demonstrably secure in many areas of North America. The species is

\footnotetext{
* See Appendix 1 for definitions of the status designations used in this section.
} 
also likely to be missed in standard surveys, may be underestimated in some counts and does not appear to be particularly threatened at present (NatureServe Explorer 2001).

Downes et al. (2000) assessed the species' status in Canada as being of medium-high concern and its management a medium responsibility. Despite the overall increase in brown creeper populations in Canada between 1966 and 1996 (Figure 4; Sauer et al. 2001), the declining trend for the species in the north, based on observations at several migration monitoring stations, is of concern. In particular, detections of migrant brown creepers have declined significantly at Delta Marsh Bird Observatory in Manitoba between 1993-2000, by $35.6 \%$ $(\mathrm{p}<0.05)$ in spring, and by $7 \%$ (not statistically significant) in fall (Bird Studies Canada 2000).

In British Columbia, the brown creeper has been given an overall rank of S4. In Saskatchewan, it has been given a rank of $\mathrm{S} 4$ during the breeding season, and a rank of S3 in the non-breeding season. In Manitoba, the species has been given an overall rank of S5.

\section{RECENT MANAGEMENT IN ALBERTA}

Until recently, little was known about the habits and habitats of the brown creeper within the province of Alberta. A number of communitylevel studies, initiated within the past decade, have provided a base of knowledge on this and other passerine species. For a summary of these projects within the province see Norton (1997). In addition to these studies, two additional projects have been recently initiated within the province of Alberta. These include:

\section{- Chip Lake Burn Study}

The Chip Lake burn study was initiated in the summer of 1998 to quantify patterns of colonization by resident (winter) and breeding (summer) bird communities in burned, salvage- logged, and unburned sites. Additional components of this study include monitoring the abundance and productivity of woodpeckers and cavity-nesting birds, quantifying differences in invertebrate species (as a measure of food availability for birds), and the distribution and characteristics of live and dead trees (as a measure of habitat structure and availability) (F. Schmiegelow, pers. comm.).

\section{- $\quad$ Remote Areas Program}

This is a large-scale project aimed at establishing links between differing levels of human disturbance in the forested regions of Alberta, and associated changes in bird community composition and structure. Data will also be used to test and refine bird-habitat models and bird monitoring methods. Surveys were initiated in 2001 in northeastern Alberta, with a goal of completing provincial coverage over the coming years. The project is currently integrated with monitoring of mammals and is intended to include other taxa in the future (F. Schmiegelow, pers. comm.).

\section{SYNTHESIS}

Little is known about the distribution, population trends, and many aspects of the general biology of the brown creeper within the province of Alberta. Because of its cryptic plumage and high-pitched call and song, this species is easily overlooked on surveys. Increasing records from more remote areas of Alberta probably reflect increased numbers of observers rather than a population expansion.

Past, current and future research projects in the province, primarily aimed at monitoring the response of songbird communities to energy and forestry sector activities, will provide much needed information on this and many other species. However, many of these projects are confined to the southern portions of the boreal forest. A recent, large-scale initiative (Remote 
Areas Program), will provide much needed distribution and abundance data for songbirds in the northern part of Alberta.

Most of the recent research in the province has been conducted in aspen-dominated forests; however, this habitat may not be the most preferred by brown creepers. Abundance estimates from other forest types, such as conifer-dominated forests are needed. Further insight into the role of disturbed habitats, such as flooded and burned areas would be beneficial. Although logistically difficult, comparisons of reproductive success or habitat quality between these habitats and other preferred habitats would be valuable. More specific information on breeding and seasonal habitat requirements are also needed to effectively manage this species in Alberta.

There is limited evidence that recent energy sector and forestry development in Alberta's boreal region have affected brown creeper populations. However, their unique life-history attributes and habitat requirements strongly suggest they may be negatively affected in the future. Further investigation into critical habitat thresholds and minimum patch size requirements would help to evaluate conservation concern and to direct management activity. 


\section{LITERATURE CITED}

Adams, E. M, and M. L. Morrison. 1993. Effects of forest stand structure and composition on red-breasted nuthatches and brown creepers. J. Wildl. Manage. 57(3): 616-629.

Alberta Environmental Protection. 1994. Alberta timber harvest planning and operating ground rules. Alberta Environmental Protection, Lands and Forest Service, Edmonton, AB. URL: http://www.gov.ab.ca/env/forests/fmd/ grndrule/groundl.html [Access date: 15 September 2001].

Alberta Fish and Wildlife. 1985. A policy for the management of threatened wildlife in Alberta. Alberta Fish and Wildlife, Edmonton, AB. 34 pp.

Alberta Fish and Wildlife. 1991. The status of Albert wildlife. Alberta Forestry, Lands and Wildlife, Fish and Wildlife Division, Edmonton, AB. 49 pp.

Alberta Natural Heritage Information Centre. 2002a. Natural Regions and Subregions of Alberta. URL: http:// www.cd.gov.ab.ca/preserving/parks/ anhic/natural_regions_map.asp. (Updated October 2002).

Alberta Natural Heritage Information Centre. 2002b. Rank Definitions. URL: http:// www.cd.gov.ab.ca/preserving/parks/ anhic/definit/asp [Revision date: October 2002].

Alberta Natural Heritage Information Centre. 2003. Elements on the Tracking List. Alberta Natural Heritage Information Centre (ANHIC). URL: http:www3.gov.ab.ca/env/parks/anhic/ anhic.html [Revision date: 3 February 2003].
Alberta Sustainable Resource Development. 2001. The General Status of Alberta Wild Species 2000. Alberta Sustainable Resource Development, Fish and Wildlife Service, Edmonton, AB. 46 pp.

Alberta Wildlife Management Division. 1996. The status of Alberta wildlife. AlbertaEnvironmental Protection, Wildlife Management Division, Edmonton, AB. 44 pp.

American Ornithologists' Union. 1998. Checklist of North American birds. $7^{\text {th }}$ ed. American Ornithologists' Union, Washington, DC. 829 pp.

Andrén, H. 1992. Corvid density and nest predation in relation to forest fragmentation: a landscape perspective. Ecology 73:794-804.

Apfelbaum, S., and A. Haney. 1977. Nesting and foraging activity in the brown creeper in northeastern Minnesota. Loon 49:78-80.

Apfelbaum, S., and A. Haney. 1981. Bird populations before and after fire in a Great Lakes pine forest. Condor 83:347354.

Baicich, P. J., and C. J. O. Harrison. 1997. A guide to the nests, eggs, and nestlings of North American birds. Academic Press, San Diego, CA. 347 pp.

Bapista, L. F., and R. B. Johnson. 1982. Song variation in insular and mainland California Brown Creepers (Certhia familiaris). J. für Ornithol. 123:131-144.

Bapista, L. F., and R. Krebs. 2000. Vocalizations and relationships of Brown Creepers Certhia americana: a taxonomic mystery. 
Bayne, E. M., and K. A. Hobson. 2000. Effects of forest fragmentation by agriculture on avian communities in the southern boreal mixedwoods of western Canada. Wilson Bull. 112(3):373-387.

Bent, A. C. 1948. Life histories of North America nuthatches, wrens, thrashers, and their allies. U. S. Natl. Mus. Bull. 195.

Bird Studies Canada. 2000. Canadian Migration Monitoring Network. URL:http:// www.bsc-eoc.org/national/ migmain.html [Last updated: 8 March 2000].

Böhning-Gaese, K. M., M. L. Taper, and J. H. Brown. 1993. Are declines in North American insectivorous birds due to causes on the breeding range? Cons. Biol. 7:76-86.

Brawn, J. D., and R. P. Balda. 1988. Population biology of cavity nesters in northern Arizona: do nest sites limit breeding densities? Condor 90:61-67.

Brewer, D., A. Diamond, E, J. Woodsworth, B. T. Collins, and E. H. Dunn. 2000. Canadian Atlas of Bird Banding, Vol. 1. Doves, cuckoos, and hummingbirds through passerines, 1921-1995. Canadian Wildlife Service, Ottawa, ON. $395 \mathrm{pp}$.

Bryant, A. A., J.-P. L. Savard, and R. T. McLaughlin. 1993. Avian communities in old-growth and managed forests of western Vancouver Island, British Columbia. Canadian Wildlife Service Technical Report Series No. 167, Delta, British Columbia. 115 pp.

Campbell, R. W., N. K. Dawe, I. McTaggartCowan, J. M. Cooper, G. W. Kaiser, M. C. E. McNall, and G. E. J. Smith. 1997.
The birds of British Columbia, Vol. 3. Passerines: flycatchers through vireos. University of British Columbia Press, Vancouver, BC. 693 pp.

Conner, R. N. 1980. Seasonal changes in woodpecker foraging patterns. Auk 98:562-570.

COSEWIC. 2001. Species at Risk in Canada. Committee on the Status of Endangered Wildlife in Canada. URL: http:// www.speciesatrisk.gc.ca/Species/sar/ main.htm [Last updated: 27 April 2001].

COSEWIC. 2002. Committee on the Status of Endangered Wildlife in Canada. URL: http://www. cosewic.gc.ca [Updated January 2002].

Cumming, S. G. 1997. Landscape dynamics of the boreal mixedwood forest. Ph.D. thesis. University of British Columbia, Vancouver, BC. $231 \mathrm{pp}$.

Cyr, A. 1974. L'avifaune nicheuse de deux types d'associations forestières dans la zone du nouvel aéroport international de Montréal à Mirabel, Québec. M.Sc. thesis, Université de Montréal, Montréal, QC. $237 \mathrm{pp}$.

Davis, C. M. 1978. A nesting study of the Brown Creeper. Living Bird 17:237263.

DeGraaf, R. M., and D. D. Rudis. 1987. New England Wildlife: habitat, natural history and distribution. USDA, For. Ser., Northeastern For. Exper. Sta., Broomal, PA. GTR NE-108. 491 pp.

Dellasala, D. A., J. C. Hagar, K. A. Engel, W. C. McComb, R. L. Fairbanks, and E. G. Campbell. 1996. Effects of silvicultural modifications of temperate rainforest on breeding and wintering bird 
communities, Prince of Wales Island, southeast Alaska. Condor 98(4): 706721.

Downes, C. M., E. H. Dunn, and C. M. Francis. 2000. Canadian landbird monitoring strategy: monitoring needs and priorities into the new millenium. Partners in Flight, Canada. Ottawa, ON. 66 pp.

Dunn, E. H. 1997. Setting priorities for conservation, research and monitoring of Canada's landbirds. Technical Report Series No. 293, Canadian Wildlife Service, Ottawa, ON. 107 pp.

Dunning, J. B. 1984. Body weights of 686 species of North American birds. Eldon Publishing, Cave Creek, AZ. 38 pp.

Erlich, P. R., D. S. Dobkin, and D. Wheye. 1988. The birder's handbook: a field guide to the natural history of North American birds. Simon and Schuster Inc., Toronto, ON. 785 pp.

Erskine, A. J. 1977. Birds in boreal Canada: communities, densities and adaptations. Canadian Wildlife Service Report Series No. 41. Ottawa, ON. 73 pp.

Farley, F. L. 1932. Birds of the Battle River region. Institute of Applied Art, Limited, Edmonton, AB. 85 pp.

Farr, D. R. 1995. Forest birds and ecosystem conservation in the Rocky Mountain foothills of Alberta. Ph.D. diss., Dept. Renew. Res., Univ. of Alberta, Edmonton, AB. 81 pp.

Franzreb, K. E. 1985. Foraging ecology of Brown Creepers in a mixed-coniferous forest. J. Field Ornithol. 56(1): 9-16.

Franzreb, K. E., and R. D. Ohmart. 1978. The effects of timber harvesting on breeding birds in a mixed-coniferous forest. Condor 80: 431-441.

Fraver, S. 1994. Vegetation responses along edge-to-interior gradients in the mixed hardwood forests of the Roanoke River basin, North Carolina. Cons. Biol. 8: 822-832.

Friedmann, H., and L. F. Kiff. 1985. The parasitic cowbirds and their hosts. Proceedings of the Western Foundation of Vertebrate Zoology 2: 226-303.

Germaine, S. S., S. H. Vessey, and D. E. Capen. 1997. Effects of small forest openings on the breeding bird community in a Vermont hardwood forest. Condor 99: 708-718.

Godfrey, W. E. 1986. The birds of Canada. National Museum of Canada, Ottawa, ON. 595 pp.

Hagan, J. M., and D. W. Johnston. 1992. Ecology and conservation of Neotropical migrant landbirds. Smithsonian Institution Press, Washington, DC.

Hagar, J. C. 1999. Influence of riparian buffer width on bird assemblages in western Oregon. J. Wildl. Manage. 63(2): 485496.

Haney, J. C. 1999. Hierchical comparisons of breeding birds in old-growth coniferhardwood forest on the Appalachian Plateau. Wilson Bull. 111(1): 89-99.

Hannah, K. C., and J. S. Hoyt. In review. Northern hawk owls and recent burns: Does burn age matter? (submitted to The Condor)

Hansen, A. J., W. C. McComb, R. Vega, M. G. Raphael, and M. Hunter. 1995. Bird habitat relationships in natural and 
managed forests in the western Cascades of Oregon. Ecol. Appl. 5(3): 555-569.

Hanula, J. L., K. E. Franzreb, and W. D. Pepper. 2000. Longleaf pine characteristics associated with arthropods available for Red-cockaded woodpeckers. J. Wildl. Manage. 64(1): 60-70.

Helle, P., and O. Järvinen. 1986. Population trends of northern Finnish landbirds in relation to their habitat selection and changes in forest structure. Oikos 46: 107-115.

Hobson, K. A., and E. Bayne. 2000a. Breeding bird communities in boreal forest of western Canada: consequences of 'unmixing' the mixedwoods. Condor 102(4): 759-769.

Hobson, K. A., and E. Bayne. 2000b. Effects of forest fragmentation by agriculture on avian communities in the southern boreal mixedwoods of western Canada. Wilson Bull. 112(3): 373-397.

Hobson, K. A., and J. Schieck. 1999. Changes in bird communities in boreal mixedwood forest: harvest and wildfire effects over 30 years. Ecol. Appl. 9(3): 849-863.

Holroyd, G. L., and K. J. Van Tighem. 1983. The ecological (biophysical) land classification of Banff and Jasper National Parks, Vol. 3, The wildlife inventory. Canadian Wildlife Service, Edmonton, AB. 691 pp.

Hooper, R. G. 1996. Arthropod biomass in winter and the use of longleaf pines. For. Ecol. and Manage. 82: 115-131.

Howell, S. N. G., and S. Webb. 1995. A guide to the birds of Mexico and northern Central America. Oxford University Press, New York, NY. 851 pp.
Hoyt, J. S. 2000. Habitat associations of Blackbacked (Picoides arcticus) and Threetoed (P. tridactylus) woodpeckers in the northeastern boreal forest of Alberta. M.Sc. thesis, Dept. of Biol. Sci., University of Alberta, Edmonton, AB. $96 \mathrm{pp}$.

Hurst, G. A., and W. E. Poe. 1985. Amino acid levels and patterns in wild turkey poults and their food items in Mississippi, pp. 133-143. In Kennamer, J. E., and M. C. Kennamer (eds.). Proceedings 5th national wild turkey Symposium, Des Moines, IA.

Hutto, R. L. 1995. Composition of bird communities following standreplacement fires in northern Rocky Mountain (U.S.A.) conifer forest. Cons. Biol. 9(5): 1041-1058.

Imbeau, L., J-P. L. Savard, and R. Gagnon. 1999. Comparing bird assemblages in successional black spruce stands originating from fire and logging. Can. J. Zool. 77: 1850-1860.

Imbeau, L., M. Monkkonen, and A. Desrochers. 2001. Long-term effects of forestry on birds of the eastern Canadian boreal forests: a comparison with Fennoscadia. Cons. Biol. 15(4): 1151-1162.

Jackson, J. A. 1979. Tree surfaces as foraging substrates for insectivorous birds, pp. 6993. In Dickson, J. G., R. N. Conner, R. R. Fleet, J. C. Kroll, and J. A. Jackson (eds.). The role of insectivorous birds in forest ecosystems. Academic Press, New York, NY.

Keller, M. E., and S. H. Anderson. 1992. Avian use of habitat configurations created by forest cutting in southeastern Wyoming. Condor 94(1): 55-65. 
Kendeigh, S. C. 1947. Bird population studies in the coniferous forest biome during a spruce budworm outbreak. Dept. Lands For Biol. Bull. 1: 1-100.

Kennard, J. H. 1975. Longevity records of North American birds. Bird-Banding 46(1): 55-73.

Kirk, D. A., A. W. Diamond, K. A. Hobson, and A. R. Smith. 1996. Breeding bird communities of the western and northern Canadian boreal forest: relationship to forest type. Can. J. Zool. 74: 1749-1770.

Lee, P. C., S. Crites, and J. B. Stelfox. 1995. Changes in forest structure and floral composition in a chronosequence of aspen mixedwood stands in Alberta. Pp. 29-48. In J. B. Stelfox (ed.). Relationship between stand age, stand structure, and biodiversity in aspen mixedwood forests in Alberta. Alberta Environmental Centre (AECV95-R1), Vegreville, AB, and Canadian Forest Service (Project No. 0001A), Edmonton, $\mathrm{AB}$.

Legg, K. 1966. Look under the bark. Audubon Mag. 68:193-194.

Levine, E. 1988. Brown Creeper. In Andrle, R. F., and J. R. Carroll (eds.). The atlas of breeding birds in New York state. Cornell University Press, Ithaca, NY. $551 \mathrm{pp}$.

Li, P., and T. E. Martin. 1991. Nest-site selection and nesting success of cavitynesting birds in high elevation forest drainages. Auk 108: 405-418.

Lima, S. L., and R. M. Lee, III. 1993. Food caching and its possible origin in the Brown Creeper. Condor 95(2): 483-484.

Lundquist, R. W., and D. A. Manuwal. 1990. Seasonal differences in foraging habitat of cavity-nesting birds in the southern Washington Cascades. In Morrison, M. L., C. J. Ralph, J. Vernor, and J. R. Jehl, Jr. (eds.). Avian foraging: theory, methodology, and applications. Stud. Avian Biol. No. 13: 218-225.

Macoun, J., and J., M. Macoun. 1909. Catalogue of Canadian birds. Geological Survey of Canada, Government Printing Office, Ottawa, ON. 761 pp.

Mannan, R. W., E. C. Meslow, and H. M. Wight. 1980. Use of snags by birds in Douglasfir forests, western Oregon. J. Wildl. Manage. 44(4): 787-797.

Mariani, J. M., and D. A. Manuwal. 1990. Factors influencing brown creeper (Certhia americana) abundance patterns in the southern Washington Cascades range. In Morrison, M. L., C. J. Ralph, J. Vernor, and J. R. Jehl, Jr. (eds.). Avian foraging: theory, methodology, and applications. Stud. Avian Biol. No. 13: 53-57

Martin, A. C., H. S. Zim, and A. L. Nelson. 1951. American wildlife and plants. McGraw Hill, New York.

McGillivray, W. B., and G. P. Semenchuk. 1998. Field Guide to Alberta Birds. Federation of Alberta Naturalists. Edmonton, AB. 350 pp.

McKenney, D. W, and D. B. Lindenmayer. 1994. An economic assessment of a nest-box strategy for the conservation of an endangered species. Can. J. For. Res. 24: 2012-2019.

Merilees, W. J. 1987. A nest box for Brown Creepers. Discovery 16: 16-17.

Morse, D. H. 1970. Ecological aspects of some mixed-species foraging flocks of birds. Ecological Monographs 40: 119-168. 
Murphy, E. C., and W. A. Lehnhausen. 1998. Density and foraging ecology of woodpeckers following a standreplacement fire. J. Wildl. Manage. 62(4): 1359-1372.

National Research Council. 1995. Science and the Endangered Species Act. National Academy Press, Washington, DC. 271 pp.

NatureServe Explorer: An online encyclopedia of life [web application]. 2001. Version 1.4. Arlington, Virginia, USA: Association for Biodiversity Information. Available: http:// www.natureserve.org/. [Accessed: 10 October 2001].

Navratil, S. 1994. Minimizing wind damage in alternative silvicultural systems in boreal mixedwoods. Canaidan Forestry Service, Northern Forestry Centre, Edmonton, AB. Canada-Alberta Partnership Agreement in Forestry Report.

Norberg, R. A. 1986. Treecreeper climbing: mechanics, energetics, and structural adaptations. Ornis Scand. 17: 191-209.

Norton, M. R. 1997. Status of the Blackthroated Green Warbler (Dendroica virens) in Alberta. Alberta Environment, Fisheries and Wildlife Management Division, and Alberta Conservation Association, Wildlife Status Report No. 23, Edmonton, AB. 24 pp.

Norton, M. R., and S. J. Hannon. 1997. Songbird response to partial-cut logging in the boreal mixedwood forest of Alberta. Can. J. For. Res. 27: 44-53.

Paynter, R. A., Jr. 1967. Check-list of birds of the world, Vol. 12. Museum of Comparative Zoology, Cambridge, MA.
Pearson, T. G. 1923. Brown Creeper. BirdLore 23: 60-63. National Association of Audobon Society Educational Leaflet \#104.

Ranney, J. W., M. C. Bruner, and J. B. Levenson. 1981. The importance of edge in the structure and dynamics of forest islands. Pp. 67-96. In Forest island dynamics in man-dominated landscapes. SpringerVerlag, New York, NY.

Raphael, M. G., and M. White. 1984. Use of snags by cavity-nesting birds in the Sierra Nevada. Wildl. Monogr. 86: 166.

Rappole, J. H, and M. V. McDonald. 1994. Cause and effect in population declines of migratory birds. Auk 111: 652-660.

Rich, A. C., D. S. Dobkin, and L. J. Niles. 1994. Defining forest fragmentation by corridor width: the influence of narrow forest-dividing corridors on forestnesting birds in southern New Jersey. Conservation Biology 8(4): 1109-1121.

Robinson, S. K., and D. S. Wilcove. 1994. Forest fragmentation in the temperate zone and its effects on migratory songbirds. Bird Conservation International 4(2-3): 233-249.

Robinson, S. K., F. R. Thompson III, T. M. Donovan, D. R. Whitehead, and J. Faaborg. 1995. Regional forest fragmentation and the nesting success of migratory birds. Science 267: 19871990.

Root, T. 1988. Atlas of wintering North American birds: an analysis of Christmas Bird Count data. University of Chicage Press, Chicage, IL. 312 pp. 
Rowe, J. S., and G. W. Scotter. 1973. Fire in the boreal forest. Quarternary Research 3: 444-464.

Rusk, M. S., and F. G. Scheider. 1966. Regional report (Region 5 - Oneida Lake Basin). Kingbird 16: 228.

Saab, V. A., and J. G. Dudley. 1998. Responses of cavity-nesting birds to stand replacement fire and salvage logging in ponderosa pine/Douglas-fir forests of southwestern Idaho. Res. Pap. RMRSRP-11. Ogden, UT: U. S. D. A., Forest Service, Rocky Mountain Research station. $17 \mathrm{pp}$.

Salt, W. R, and J. R. Salt. 1976. The birds of Alberta. Hurtig Publishers, Edmonton, AB. $498 \mathrm{pp}$.

Sampson, G. R., S. A. Ernst, and F. A. Ruppert. 1985. Lumber recovery of live and firekilled white spruce. Pp. 17-19 In G. P. Juday and C. T. Dyrness (eds.). Early results of the Rosie Creek Fire Research Project 1984. Univ. Alaska-Fairbanks. Agric. For. Exper. Sta. Misc. Publ. 852.

Sauer, J. R., J. E. Hines, and J. Fallon. 2001. The North American Breeding Bird Survey, Results and Analysis 19662000. Version 2001.2. USGS Patuxent Wildlife Research Centre, Laurel, MD. URL: http://www.mbr.nbs.gov/bbs/ bbs.html [Revision date: 24 June 2001].

Scheider, F. G. 1971. Highlights of the summer season. Kingbird 21: 215.

Schieck, J., and M. Nietfeld. 1995. Bird species richness and abundance in relation to stand age and structure in aspen mixedwood forests in Alberta. In Relationships between stand age, stand structure, and biodiversity in aspen mixedwood forests in Alberta. J. B. Stelfox (ed.). Alberta Environmental Centre (AECV95-R1), Vegreville, AB, and Canadian Forest Service (Project No. 0001A), Edmonton, AB.

Schieck, J., K. Stuart-Smith, and M. Norton. 2000. Bird communities are affected by amount and dispersion of vegetation retained in mixedwood boreal forest harvest areas. For. Ecol. Manage. 126: 239-254.

Schmiegelow, F. K. A. 1997. The effect of experimental fragmentation on bird community dynamics in the boreal mixedwood forest. Ph.D. diss., Dept. of Zool., Univ. British Columbia. 140 pp.

Schmiegelow, F. K. A., and S. J. Hannon. 1993. Adaptive management, adaptive science and the effects of forest fragmentation on boreal birds in northern Alberta. Trans. N. A. Wildl. Natur. Res. Conf. 58: 584-598.

Schmiegelow, F. K. A., C. S. Machtans, and S. J. Hannon. 1997. Are boreal birds resilient to forest fragmentation? An experimental study of short-term community responses. Ecology 78(6): 1914-1932.

Semenchuk, G. P. (ed.). 1992. The atlas of the breeding birds of Alberta. Federation of Alberta Naturalists'. Edmonton, AB. $390 \mathrm{pp}$.

Shaffer, F., and R. Alvo. 1996. Brown Creeper, pp. 748-751 in Gauthier, J., and Y. Aubry, (eds.). The breeding birds of Quebec. Association quebecoise des groupes d'ornithologues, Province of Quebec Society for the Protection of Birds, Canadian Wildlife Service, Env. Canada, Quebec region, Montreal, QC. $1302 \mathrm{pp}$. 
Sherry, T. W., and R. T. Holmes. 1993. Are populations of Neotropical migrant birds limited in summer or winter? Implications for management, pp. 4757. In Finch, D. M., and T. W. Stangel, (eds.). Status and management of Neotropical migratory birds. USDA Forest Service, Rocky Mountain Range and Experimental Station. Research Note RM-229.

Sherry, T. W., and R. T. Holmes. 1996. Winter habitat quality, population limitation, and conservation of NeotropicalNearctic migrant birds. Ecology 77(1): 36-48.

Terres, J. K. 1980. The Audubon Society encyclopedia of birds. Knopf, New York, NY. 1109 pp.

Thielcke, G. 1962. Versuche mit Klangattrappan zur Klärang der Verwandtschaft der Baumläufer (Certhia familiaris) L., (C. brachydactyla) Brehm and $(C$. americana) Bonaparte. Journal für Ornithologie 103: 266-271

Tittler, R. 1998. Effects of residual tree retention on breeding songbirds in Alberta's boreal mixed-wood forest. M.Sc. thesis, University of Alberta, Edmonton, AB. 98 pp.

Vaurie, C. 1957. Systematic notes on palearctic birds, No. 30. The Certhiidae. Amer. Mus. Novitates 1855.
Von Haartman, L. 1956. Adaptations in holenesting birds. Evolution 11: 339-347.

Weikel, J. M., and J. P. Hayes. 1999. The foraging ecology of cavity-nesting birds in young forests of the northern coast range of Oregon. Condor 101(1): 5866.

Whitcomb, R. F., C. S. Robbins, J. F. Lynch, B. L. Whitcomb, M. K. Klimkewitz, and D. Bystrak. 1981. Effects of forest fragmentation on avifauna of the eastern deciduous forest. Pp. 125-205. In R. L. Burgess and D. M. Sharpe (Eds.). Forest island dynamics in man-dominated landscapes. Springer-Verlag, New York, NY.

Williams, J. B., and G. O. Batzli. 1979. Winter diet of a bark-foraging guild of birds. Wilson Bull. 91(1): 126-131.

Wilson, M. F. 1970. Foraging behavior of some winter birds of deciduous woods. Condor 72(2): 169-174.

Yahner, R. H. 1988. Changes in wildlife communities near edges. Conservation Biology 2(4): 333-339.

Zarnowitz, J. E., and D. A. Manuwal. 1985. The effects of forest management on cavitynesting birds in northwestern Washington. J. Wildl. Manage. 49(1): 255-263. 
Appendix 1. Definitions of selected legal and protective designations.

A. The General Status of Alberta Wild Species 2000 (after Alberta Sustainable Resource Development 2001)

\begin{tabular}{|c|c|c|}
\hline 2000 Rank & 1996 Rank & Definitions \\
\hline At Risk & Red & $\begin{array}{l}\text { Any species known to be "At Risk" after formal detailed status } \\
\text { assessment and designation as "Endangered" or "Threatened" in } \\
\text { Alberta. }\end{array}$ \\
\hline May Be At Risk & Blue & $\begin{array}{l}\text { Any species that may be at risk of extinction or extirpation, and is } \\
\text { therefore a candidate for detailed risk assessment. }\end{array}$ \\
\hline Sensitive & Yellow & $\begin{array}{l}\text { Any species that is not at risk of extinction or extirpation but may } \\
\text { require special attention or protection to prevent it from becoming } \\
\text { at risk. }\end{array}$ \\
\hline Secure & Green & $\begin{array}{l}\text { Any species that is not "At Risk", "May Be At Risk", or } \\
\text { "Sensitive". }\end{array}$ \\
\hline Undetermined & $\begin{array}{l}\text { Status } \\
\text { Undetermined }\end{array}$ & $\begin{array}{l}\text { Any species for which insufficient information, knowledge or data } \\
\text { is available to reliably evaluate its general status. }\end{array}$ \\
\hline Not Assessed & $\mathrm{n} / \mathrm{a}$ & $\begin{array}{l}\text { Any species known or believed to be present but which has not yet } \\
\text { been evaluated. }\end{array}$ \\
\hline Exotic/Alien & $\mathrm{n} / \mathrm{a}$ & $\begin{array}{l}\text { Any species that has been introduced as a result of human } \\
\text { activities. }\end{array}$ \\
\hline Extirpated/Extinct & $\mathrm{n} / \mathrm{a}$ & $\begin{array}{l}\text { Any species no longer thought to be present in Alberta } \\
\text { ("Extirpated") or no longer believed to be present anywhere in the } \\
\text { world ("Extinct"). }\end{array}$ \\
\hline Accidental/Vagrant & $\mathrm{n} / \mathrm{a}$ & $\begin{array}{l}\text { Any species occurring infrequently and unpredictably in Alberta, } \\
\text { i.e., outside their usual range. }\end{array}$ \\
\hline
\end{tabular}

\section{B. Alberta Wildlife Act/Regulation}

Species designated as "Endangered" under Alberta's Wildlife Act include those listed as "Endangered" or "Threatened" in the Wildlife Regulation.

\begin{tabular}{|l|l} 
Endangered & A species facing imminent extirpation or extinction.
\end{tabular}

Threatened A species that is likely to become endangered if limiting factors are not reversed.

\section{Committee on the Status of Endangered Wildlife in Canada (after COSEWIC 2002)}

\begin{tabular}{|l|l|}
\hline Extinct & A species that no longer exists. \\
\hline Extirpated & A species that no longer exists in the wild in Canada, but occurs elsewhere. \\
\hline Endangered & A species facing imminent extirpation or extinction. \\
\hline Threatened & A species that is likely to become endangered if limiting factors are not reversed. \\
\hline Special Concern & $\begin{array}{l}\text { A species of special concern because of characteristics that make it particularly } \\
\text { sensitive to human activities or natural events. }\end{array}$ \\
\hline Not at Risk & A species that has been evaluated and found to be not at risk. \\
\hline Data Deficient & $\begin{array}{l}\text { A species for which there is insufficient scientific information to support status } \\
\text { designation. }\end{array}$ \\
\hline
\end{tabular}


D. Heritage Status Ranks: Global (G), National (N), Sub-National (S) (after Alberta Natural Heritage Information Centre 2002b)

\begin{tabular}{|l|l|}
\hline G1/N1/S1 & $\begin{array}{l}\text { 5 or fewer occurrences or only a few remaining individuals. May be especially } \\
\text { vulnerable to extirpation because of some factor of its biology. }\end{array}$ \\
\hline G2/N2/S2 & $\begin{array}{l}\text { 6-20 or fewer occurrences or with many individuals in fewer locations. May be } \\
\text { especially vulnerable to extirpation because of some factor of its biology. }\end{array}$ \\
\hline G3/N3/S3 & $\begin{array}{l}\text { 21-100 occurrences, may be rare and local throughout its range, or in a restricted range } \\
\text { (may be abundant in some locations). May be susceptible to extirpation because of } \\
\text { large-scale disturbances. }\end{array}$ \\
\hline G4/N4/S4 & Typically $>100$ occurrences. Apparently secure. \\
\hline G5/N5/S5 & Typically $>100$ occurrences. Demonstrably secure. \\
\hline GX/NX/SX & Believed to be extinct or extirpated, historical records only. \\
\hline GH/NH/SH & Historically known, may be relocated in future. \\
\hline GR/NR/SR & Reported, but lacking in documentation \\
\hline
\end{tabular}

E. United States Endangered Species Act (after National Research Council 1995)

\begin{tabular}{|l|l|}
\hline Endangered & $\begin{array}{l}\text { Any species which is in danger of extinction throughout all or a significant portion of } \\
\text { its range. }\end{array}$ \\
\hline Threatened & $\begin{array}{l}\text { Any species which is likely to become an endangered species within the foreseeable } \\
\text { future throughout all or a significant portion of its range. }\end{array}$ \\
\hline
\end{tabular}




\section{List of Titles in This Series}

(as of June 2003)

No. 1 Status of the Piping Plover (Charadrius melodus) in Alberta, by David R. C. Prescott. 19 pp. (1997)

No. 2 Status of the Wolverine (Gulo gulo) in Alberta, by Stephen Petersen. 17 pp. (1997)

No. 3 Status of the Northern Long-eared Bat (Myotis septentrionalis) in Alberta, by M. Carolina Caceres and M. J. Pybus. 19 pp. (1997)

No. 4 Status of the Ord's Kangaroo Rat (Dipodomys ordii) in Alberta, by David L. Gummer. 16 pp. (1997)

No. 5 Status of the Eastern Short-horned Lizard (Phrynosoma douglassii brevirostre) in Alberta, by Janice D. James, Anthony P. Russell and G. Lawrence Powell. 20 pp. (1997)

No. 6 Status of the Prairie Rattlesnake (Crotalus viridis viridis) in Alberta, by Sheri M. Watson and Anthony P. Russell. 26 pp. (1997)

No. 7 Status of the Swift Fox (Vulpes velox) in Alberta, by Susan E. Cotterill. 17 pp. (1997)

No. 8 Status of the Peregrine Falcon (Falco peregrinus anatum) in Alberta, by Petra Rowell and David P. Stepnisky. 23 pp. (1997)

No. 9 Status of the Northern Leopard Frog (Rana pipiens) in Alberta, by Greg Wagner. 46 pp. (1997)

No. 9 Update 2003. Status of the Northern Leopard Frog (Rana pipiens) in Alberta. Alberta Sustainable Resource Development. 61 pp. (2003)

No. 10 Status of the Sprague's Pipit (Anthus spragueii) in Alberta, by David R. C. Prescott. 14 pp. (1997)

No. 11 Status of the Burrowing Owl (Speotyto cunicularia hypugaea) in Alberta, by Troy I. Wellicome. $21 \mathrm{pp}$. (1997)

No. 12 Status of the Canadian Toad (Bufo hemiophrys) in Alberta, by Ian M. Hamilton, Joann L. Skilnick, Howard Troughton, Anthony P. Russell, and G. Lawrence Powell. 30 pp. (1998)

No. 13 Status of the Sage Grouse (Centrocercus urophasianus urophasianus) in Alberta, by Cameron L. Aldridge. 23 pp. (1998)

No. 14 Status of the Great Plains Toad (Bufo cognatus) in Alberta, by Janice D. James. 26 pp. (1998)

No. 15 Status of the Plains Hognose Snake (Heterodon nasicus nasicus) in Alberta, by Jonathan Wright and Andrew Didiuk. 26 pp. (1998)

No. 16 Status of the Long-billed Curlew (Numenius americanus) in Alberta, by Dorothy P. Hill. 20 pp. (1998)

No. 17 Status of the Columbia Spotted Frog (Rana luteiventris) in Alberta, by Janice D. James. 21 pp. (1998)

No. 18 Status of the Ferruginous Hawk (Buteo regalis) in Alberta, by Josef K. Schmutz. 18 pp. (1999)

No. 19 Status of the Red-tailed Chipmunk (Tamias ruficaudus) in Alberta, by Ron Bennett. 15 pp. (1999)

No. 20 Status of the Northern Pygmy Owl (Glaucidium gnoma californicum) in Alberta, by Kevin C. Hannah. 20 pp. (1999) 
No. 21 Status of the Western Blue Flag (Iris missouriensis) in Alberta, by Joyce Gould. 22 pp. (1999)

No. 22 Status of the Long-toed Salamander (Ambystoma macrodactylum) in Alberta, by Karen L. Graham and G. Lawrence Powell. 19 pp. (1999)

No. 23 Status of the Black-throated Green Warbler (Dendroica virens) in Alberta, by Michael R. Norton. 24 pp. (1999)

No. 24 Status of the Loggerhead Shrike (Lanius ludovicianus) in Alberta, by David R. C. Prescott and Ronald R. Bjorge. 28 pp. (1999)

No. 25 Status of the Plains Spadefoot (Spea bombifrons) in Alberta, by Richard D. Lauzon. 17 pp. (1999)

No. 26 Status of the Trumpeter Swan (Cygnus buccinator) in Alberta, by M. Lynne James. 21 pp. (2000)

No. 27 Status of the Pygmy Whitefish (Prosopium coulteri) in Alberta, by William C. Mackay. 16 pp. (2000)

No. 28 Status of the Short-eared Owl (Asio flammeus) in Alberta, by Kort M. Clayton. 15 pp. (2000)

No.29 Status of the Willow Flycatcher (Empidonax traillii) in Alberta, by Bryan Kulba and W. Bruce McGillivray. 15 pp. (2001).

No.30 Status of the Woodland Caribou (Rangifer tarandus caribou) in Alberta, by Elston Dzus. 47 pp. (2001)

No.31 Status of the Western Spiderwort (Tradescantia occidentalis) in Alberta, by Bonnie Smith. 12 pp. (2001)

No.32 Status of the Bay-breasted Warbler (Dendroica castanea) in Alberta, by Michael Norton. 21 pp. (2001)

No. 33 Status of the Cape May Warbler (Dendroica tigrina) in Alberta, by Michael Norton. 20 pp. (2001)

No. 34 Status of the Whooping Crane (Grus americana) in Alberta, by Jennifer L. White. 21 pp. (2001)

No. 35 Status of Soapweed (Yucca glauca) in Alberta, by Donna Hurlburt. 18 pp. (2001)

No. 36 Status of the Harlequin Duck (Histrionicus histrionicus) in Alberta, by Beth MacCallum. 38 pp. (2001)

No. 37 Status of the Grizzly Bear (Ursus arctos) in Alberta, by John L. Kansas. 43 pp. (2002)

No. 38 Status of the Wood Bison (Bison bison athabascae) in Alberta, by Jonathan A. Mitchell and C. Cormack Gates. 32 pp. (2002)

No. 39 Status of the Bull Trout (Salvelinus confluentus) in Alberta, by John R. Post and Fiona D. Johnston. 40 pp. (2002)

No. 40 Status of the Banff Springs Snail (Physella johnsoni) in Alberta, by Dwayne A.W. Lepitzki. 29 pp. (2002)

No. 41 Status of the Shortjaw Cisco (Coregonus zenithicus) in Alberta, by Mark Steinhilber. 23 pp. (2002)

No. 42 Status of the Prairie Falcon (Falco mexicanus) in Alberta, by Dale Paton. 28 pp. (2002)

No. 43 Status of the American Badger (Taxidea taxus) in Alberta, by Dave Scobie. 17 pp. (2002)

No. 44 Status of the Yucca Moth (Tegeticula yuccasella) in Alberta. Alberta Sustainable Resource Development. 21 pp. (2002) 
No. 45 Status of the White-winged Scoter (Melanitta fusca deglandi) in Alberta. Alberta Sustainable Resource Development. 15 pp. (2002)

No. 46 Status of the Lake Sturgeon (Acipenser fulvescens) in Alberta. Alberta Sustainable Resource Development. 30 pp. (2002)

No. 47 Status of the Western Silvery Minnow (Hybognathus argyritis) in Alberta. Alberta Sustainable Resource Development. 24 pp. (2003)

No.48 Status of the Small-flowered Sand Verbena (Tripterocalyx micranthus) in Alberta. Alberta Sustainable Resource Development. 24 pp. (2003)

No. 49 Status of the Brown Creeper (Certhia americana) in Alberta. Alberta Sustainable Resource Development. 30 pp. (2003) 

National Library of Canada Bibliotheque nationale du Canada 